Article

\title{
High Mobility Group Box 1 and TLR4 Signaling Pathway in Gnotobiotic Piglets Colonized/Infected with L. amylovorus, L. mucosae, E. coli Nissle 1917 and $S$. Typhimurium
}

\author{
Igor Splichal ${ }^{1}\left(\mathbb{D}\right.$, Sharon M. Donovan $\left.{ }^{2}{ }^{(}\right)$, Vera Jenistova ${ }^{1}$, Iva Splichalova ${ }^{3}(\mathbb{0}$, \\ Hana Salmonova ${ }^{4}\left({ }^{\circ}\right.$, Eva Vlkova ${ }^{4}\left(\mathcal{D}\right.$, Vera Neuzil Bunesova ${ }^{4}\left({ }^{\circ}\right.$, Marek Sinkora ${ }^{1}$, Jiri Killer ${ }^{4,5}$, \\ Eva Skrivanova ${ }^{4}$ and Alla Splichalova ${ }^{1, *}$ (i) \\ 1 Laboratory of Gnotobiology, Institute of Microbiology, Czech Academy of Sciences, 54922 Novy Hradek, \\ Czech Republic; splichal@gnotobio.cz (I.S.); jenistova@gnotobio.cz (V.J.); marek@biomed.cas.cz (M.S.) \\ 2 Department of Food Science and Human Nutrition, University of Illinois, Urbana, IL 61801, USA; \\ sdonovan@illinois.edu \\ 3 Laboratory of Immunobiology, Institute of Molecular Genetics, Czech Academy of Sciences, 14220 Prague, \\ Czech Republic; iva.splichalova@img.cas.cz \\ 4 Department of Microbiology, Nutrition and Dietetics, Faculty of Agrobiology, Food and Natural Resources, \\ Czech University of Life Sciences in Prague, 16500 Prague, Czech Republic; salmonova@af.czu.cz (H.S.); \\ vlkova@af.czu.cz (E.V.); bunesova@af.czu.cz (V.N.B.); killer@iapg.cas.cz (J.K.); skrivanovae@af.czu.cz (E.S.) \\ 5 Laboratory of Anaerobic Microbiology, Institute of Animal Physiology and Genetics, \\ Czech Academy of Sciences, 14220 Prague, Czech Republic \\ * Correspondence: splichalova@gnotobio.cz; Tel.: +420-491-418-539
}

Received: 24 October 2019; Accepted: 10 December 2019; Published: 13 December 2019 updates

\begin{abstract}
High mobility group box 1 (HMGB1) is a DNA-binding nuclear protein that can be actively secreted by immune cells after different immune stimuli or passively released from cells undergoing necrosis. HMGB1 amplifies inflammation, and its hypersecretion contributes to multiple organ dysfunction syndrome and death. We tested possible immunomodulatory effect of commensal Lactobacillus amylovorus (LA), Lactobacillus mucosae (LM) or probiotic Escherichia coli Nissle 1917 (EcN) in infection of gnotobiotic piglets with Salmonella Typhimurium (ST). Transcription of HMGB1 and Toll-like receptors (TLR) 2, 4, and 9 and receptor for advanced glycation end products (RAGE), TLR4-related molecules (MD-2, CD14, and LBP), and adaptor proteins (MyD88 and TRIF) in the ileum and colon were measured by RT-qPCR. Expression of TLR4 and its related molecules were highly upregulated in the ST-infected intestine, which was suppressed by EcN, but not LA nor LM. In contrast, HMGB1 expression was unaffected by ST infection or commensal/probiotic administration. HMGB1 protein levels in the intestine measured by ELISA were increased in ST-infected piglets, but they were decreased by previous colonization with E. coli Nissle 1917 only. We conclude that the stability of HMGB1 mRNA expression in all piglet groups could show its importance for DNA transcription and physiological cell functions. The presence of HMGB1 protein in the intestinal lumen probably indicates cellular damage.
\end{abstract}

Keywords: Escherichia coli Nissle 1917 (EcN); gnotobiotic piglet; high mobility group box 1 (HMGB1); intestine; Lactobacillus amylovorus (LA); Lactobacillus mucosae (LM); Salmonella Typhimurium (ST); Toll-like receptor 4 (TLR4) 


\section{Introduction}

High mobility group box 1 (HMGB1) is an intracellular nuclear DNA-binding protein that can be produced by innate immune cells or released from cells undergoing necrosis [1]. This evolutionarily conserved protein shows high interspecies amino acid homology [2] and participates in different processes, including transcription, replication, nucleosome formation, and tissue repair [3]. It is essential for life, as it was documented in mouse pups with deleted HMGB1 that were born alive, but died within $24 \mathrm{~h}$ [4]. HMGB1 belongs to damage-associated molecular patterns (DAMPs) called alarmins. The alarmins are endogenous intracellular factors that are normally hidden from immune recognition, but in some conditions, such as cellular stress or injury, they can be released to the cell vicinity and sensed $[1,5,6]$. Circulating HMGB1 arises from a combination of both active secretion and passive release from cells of different lineages [7]. It can either promote beneficial tissue repair and provoke deleterious uncontrolled inflammation [8].

Gram-positive and Gram-negative bacteria induce different inflammatory cytokine patterns [9] and their levels are higher in septic non-survivors compare to survivors [10]. HMGB1 shows cytokine activity [1]. It is released later in infections compared to inflammatory cytokines, as tumor necrosis factor (TNF)- $\alpha$ and interleukin (IL)-1 $\beta$ [11]. The exaggerated secretion/release of HMGB1 has a detrimental effect on surviving patients with sepsis [12]. The active secretion of HMGB1 undergoing to changes (acetylation, phosphorylation, and methylation) [13-15] and its passive release [16] can amplify innate immune response to multiple organ dysfunction syndrome and death [11,17]. Therefore, the increased levels of HMGB1 predict multiple organ dysfunction syndrome (MODS) with fatal consequences of infection [17]; thus, increased systemic HMGB1 is considered a biomarker of sepsis [11].

In contrast to DAMPs, pathogen-associated molecular patterns (PAMPs) are molecular structures typical for microorganisms [18]. Both PAMPs and DAMPs are recognized by pattern recognition receptors (PRRs) [19]. Toll-like receptors (TLRs) are one of the PRRs groups. TLR2, 4, and 9 recognize typical bacterial structures as well as HMGB1 [19-21]. A receptor for advanced glycation end (RAGE) is another HMGB1 recognizing receptor [5]. The shared recognition of PAMPs and DAMPs by the same receptors leads to similar activations and consequences in infections and sterile tissue traumas of various origins [22,23]. The need to re-evaluate old definition of sepsis [24] and update it [25] based on these novel molecular findings.

Closely related human and pig anatomy, genetics, physiology [26], and highly similar composition of microbiome [27] predetermine the pig as an animal model of human infectious [28] and gastroenterological diseases [29]. Salmonella enterica serovar Typhimurium (S. Typhimurium) commonly causes gastroenteritis (salmonellosis) in humans and pigs [30] but human typhoid fever-like illness in mice [31]. S. Typhimurium can also cause life-threatening invasive diseases in immunocompromised individuals [32]. The intracellular environment and frequent multidrug resistance protect Salmonella enterica against extracellular antibiotics and facilitates disease relapse [33-35]. Thus, it is necessary to look for alternative ways to combat infections with this foodborne pathogen [36,37]. One possibility is the modulation of the GIT microbiota by commensal and probiotic bacteria [38].

Lactobacillus spp. are Gram-positive facultative anaerobes that create an abundant bacterial group in human and pig microbiota in the distal small intestine and colon $[39,40]$. A strain-specific beneficial effect of lactobacilli is determined by high variability in composition of cell wall polysaccharides, peptidoglycan, and teichoic acids, membrane lipoproteins and lipoteichoic acids that can differentially induce the host immune response [41]. Moreover, all Lactobacillus spp. produce organic acids with antimicrobial properties and some species also produce other antimicrobial compounds, such as bacteriocins and $\mathrm{H}_{2} \mathrm{O}_{2}$ [42]. Despite the fact that Lactobacillus spp. are typically beneficial for the host, care should be taken with their application in immunocompromised hosts [43] and all new probiotic bacteria should be tested for their antimicrobial susceptibility [44]. Some lactobacilli strains, such as L. rhamnosus GG, L. casei Shirota, and L. acidophilus LB, are widely used probiotics [45], and commensal lactobacilli strains have been used to combat enteric pathogens [46,47]. Another abundant bacterial group in the intestinal tract are Gram-negative Escherichia coli that includes both pathogenic [48] 
and probiotic [49] strains. A probiotic E. coli Nissle 1917 (EcN) is anti-diarrheic in humans [50] and pigs [51]. This effect of EcN is mediated mainly by the production of colicins, microcins, and siderofores, and other systems for iron uptake [52].

Gnotobiotic animals have, in contrast to conventional animals, simple and defined microbiota [53]. Their lowered colonization resistance [54] suggests these animal models for the study of microbe versus host interactions with less virulent microbes that would be normally suppressed in the presence of a balanced microbiota [55]. Moreover, colostrum-free piglets are immunocompromised by deprivation of maternal immunoglobulins and cells [56]. Therefore, germ-free surgery-derived piglets that are reared in microbiologically controlled conditions can be used as a model of vulnerable immunocompromised infants [57]. Salmonella Typhimurium strain LT2 is a well-characterized laboratory strain [58]. It was safe for one-week-old conventional piglets after its oral application [59], but it caused gastroenteritis and sepsis in immunocompromised germ-free piglets of the same age [60].

Our work aimed to describe intestinal HMGB1 release after infection of gnotobiotic piglets with Gram-negative enteric pathogen Salmonella Typhimurium, signaling via TLR2, TLR4, TLR9, and RAGE, and the possible influence of previous colonization of the piglets with commensal Gram-positive lactobacilli Lactobacillus amylovorus and Lactobacillus mucosae or probiotic Gram-negative E. coli Nissle 1917. Knowledge of innate immune regulations and possibilities to modify TLRs signaling pathways can be helpful for the development of advanced therapeutic procedures to ameliorate health problems in the $S$. Typhimurium infections, especially in life-threatened immunocompromised individuals.

\section{Results}

\section{1. mRNA Relative Expressions of TLR4 and Its Related Molecules, TLR2, TLR9, and RAGE, in the Ileum}

Eight groups of gnotobiotic piglets were used in the experiments (Supplementary Figure S1)—(i) germ-free (GF); (ii) GF piglets infected with $S$. Typhimurium (ST); (iii) GF piglets colonized with L. amylovorus (LA); (iv) LA piglets infected with S. Typhimurium (LA+ST); (v) GF piglets colonized with L. mucosae (LM); (vi) LM piglets infected with S. Typhimurium (LM+ST); (vii) GF piglets colonized with E. coli Nissle 1917 (EcN), and (viii) EcN piglets infected with S. Typhimurium (EcN+ST).

Neither commensal L. amylovorus (LA) and L. mucosae (LM) nor probiotic E. coli Nissle 1917 (EcN) influenced TLR4 transcription in the ileum of the gnotobiotic piglets (Figure 1A). S. Typhimurium significantly upregulated mRNA expression of TLR4 in the ST, LA+ST, and LM+ST groups, but not in the EcN+ST piglets. LA, LM, and EcN slightly upregulated transcriptions of MD2 (Figure 1B) compare to the GF piglets. The upregulation was statistically significant in the ST, LA+ST, and LM+ST, but not in the EcN+ST group. Similarly to TLR4, a statistically significant upregulation of CD14 was induced by S. Typhimurium (Figure 1C), but previous colonization with E. coli Nissle 1917 prevented this upregulation. Comparable results were observed in lipopolysaccharide binding protein (LBP) (Figure 1D). Statistically significant upregulation of MyD88 expression was observed in the ST, LA+ST and LM+ST groups, but not the EcN+ST group (Figure 1E). In contrast, this was not observed in TRIF (Figure 1F), where no statistical significance between the GF and other groups was found. The TLR2 expression (Figure 1G) showed a similar pattern and statistical significance as to TLR4. In contrast to TLR2 and TLR4, no effect was observed in TLR9 expression (Figure 1H), and all groups were similar to the GF group. RAGE (Figure 1I) also did not show any obvious trend, and only the LM group only was statistically different from the control GF group. 

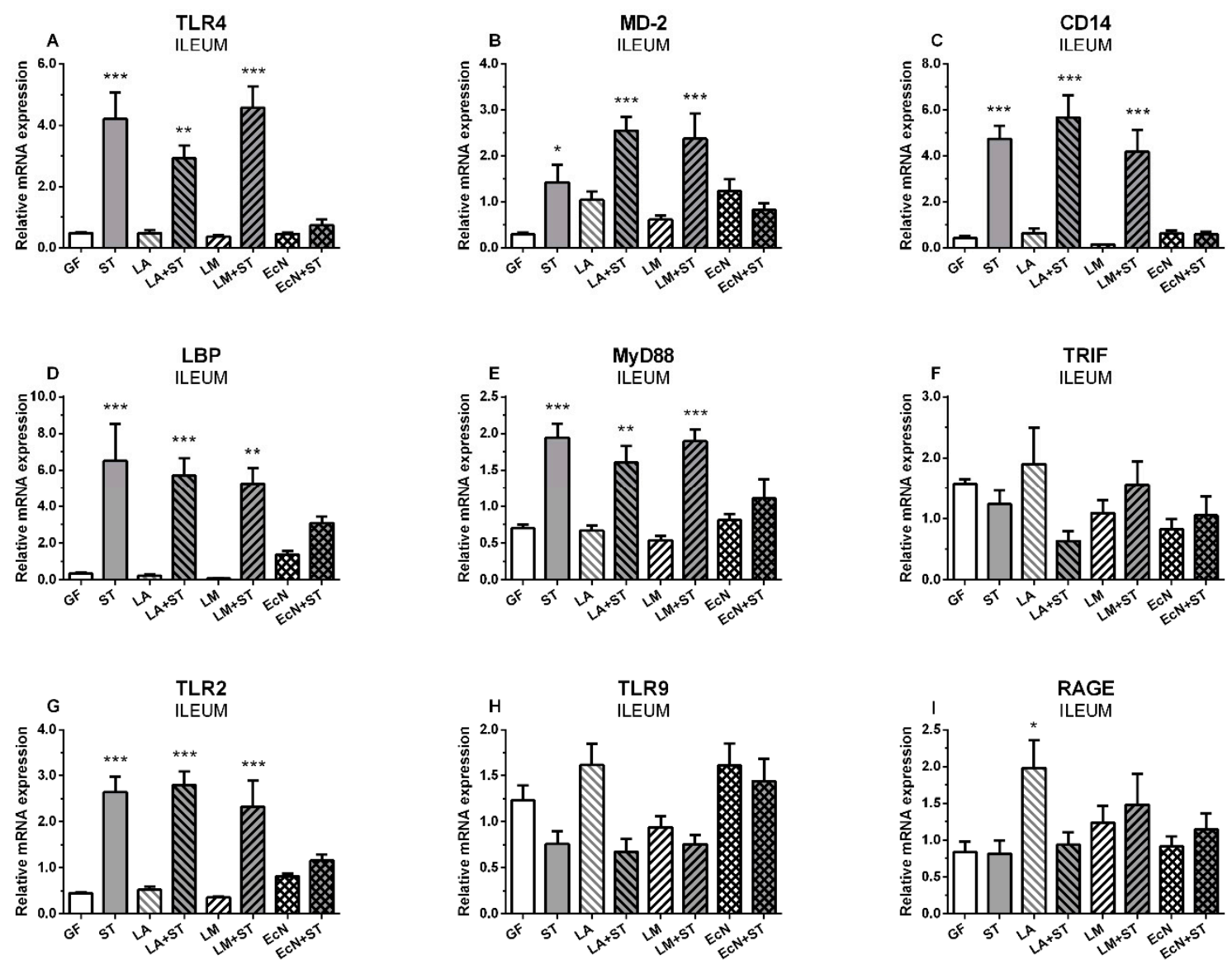

Figure 1. mRNA relative expression (fold change) of TLR4 and its related molecules, TLR2, TLR9, and RAGE in the ileum. TLR4 (A), MD-2 (B), CD-14 (C), LBP (D), MyD88 (E), TRIF (F), TLR2 (G), TLR9 $(\mathbf{H})$, and RAGE (I) are presented as mean + SEM. Differences between the control GF group and other groups were evaluated by one-way analysis of variance (ANOVA) with Dunnett's multiple comparison post-hoc test and depicted ${ }^{*} p<0.05,{ }^{* *} p<0.01,{ }^{* *} p<0.001 ; n=6$ for each group.

\section{2. mRNA Relative Expressions of TLR4 and Its Related Molecules, TLR2, TLR9, and RAGE, in the Colon}

The relative mRNA expression of TLR4 in the colon (Figure 2A) was upregulated in all S. Typhimurium infected groups (ST, $\mathrm{LA}+\mathrm{ST}, \mathrm{LM}+\mathrm{ST}$, and $\mathrm{EcN}+\mathrm{ST}$ ) compared to GF group. MD2 showed statistically significant upregulation in LM+ST only (Figure 2B). TLR4 coreceptor CD14 (Figure 2C) showed significantly higher mRNA expression in all Salmonella-infected piglets ST, LA+ST, and $\mathrm{LM}+\mathrm{ST}$, except those formerly colonized with probiotic $E$. coli $(\mathrm{EcN}+\mathrm{ST})$. In contrast, LBP expression (Figure 2D) was upregulated in all Salmonella-infected groups without any exception. MyD88 (Figure 2E) and TRIF (Figure 2F) expression showed opposite trends and also showed different expression profiles than in the ileum. While MyD88 expression (Figure 2E) was significantly upregulated in the ST, $\mathrm{LA}+\mathrm{ST}$, and EcN+ST groups, TRIF expression was reduced (Figure 2F) in all Salmonella-infected groups, but was statistically significant downregulated in the groups previously colonized with lactobacilli (LA+ST and LM+ST) only. TLR2 did not show any obvious pattern (Figure 2G) except that expression was significantly greater in the EcN+ST group compared to the GF control. The TLR9 expression (Figure $2 \mathrm{H}$ ) was statistically significantly upregulated in the groups colonized with EcN (EcN and EcN+ST) only. RAGE as TLR2 did not show any obvious trend (Figure 2I). 

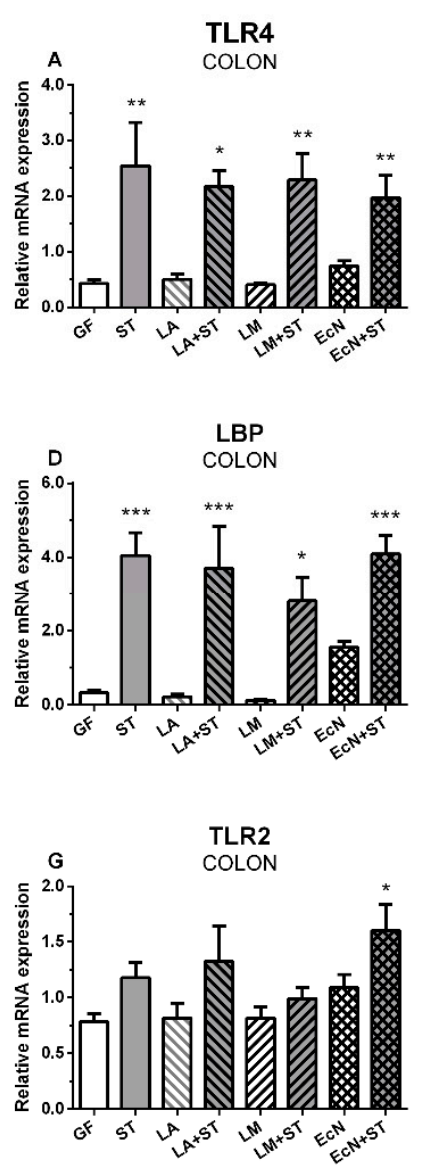
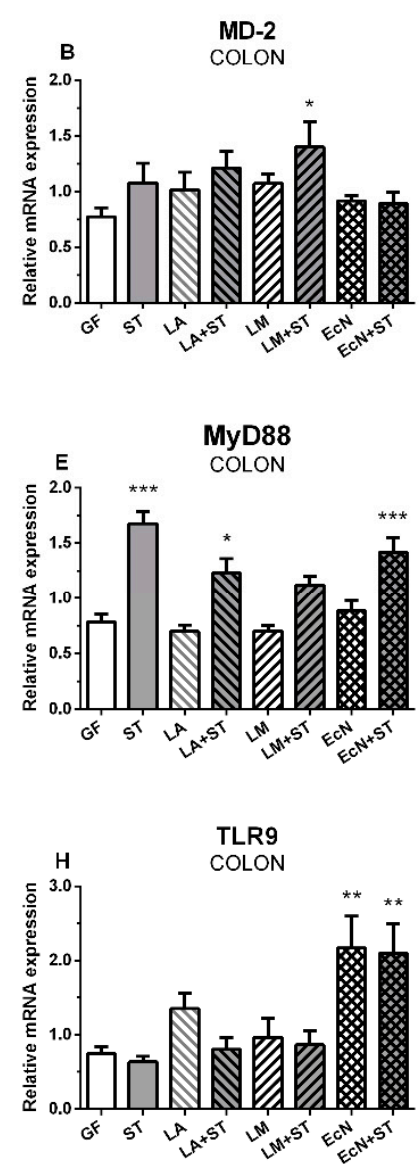
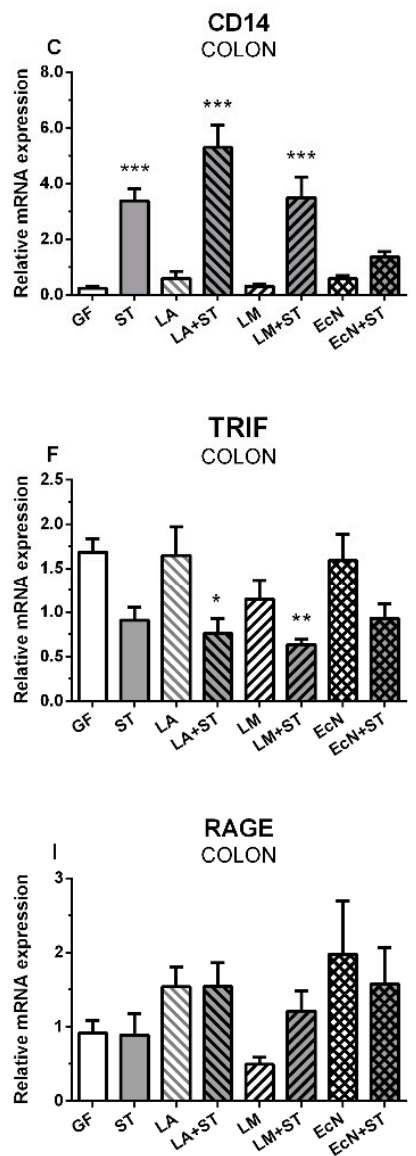

Figure 2. mRNA relative expression (fold change) of TLR4 and its related molecules, TLR2, TLR9, and RAGE in the colon. TLR4 (A), MD-2 (B), CD-14 (C), LBP (D), MyD88 (E), TRIF (F), TLR2 (G), TLR9 $(\mathbf{H})$, and RAGE (I) are presented as mean + SEM. Differences between the control GF group and other groups were evaluated by one-way analysis of variance (ANOVA) with Dunnett's multiple comparison post-hoc test and depicted ${ }^{*} p<0.05,{ }^{* *} p<0.01,{ }^{* *} p<0.001 ; n=6$ for each group.

2.3. $m R N A$ Relative Expressions of TLR4 and Its Related Molecules, TLR2, TLR9, and RAGE in Mesenteric Lymph Nodes

The relative expression of TLR4 was upregulated in mesenteric lymph nodes (MLN) of the groups infected with Salmonella (ST, LA+ST, and LM+ST), but only in the group precolonized with L. mucosae was this upregulation statistically significant (Figure 3A). MD-2 was increased in the LM+ST group only (Figure 3B). The groups infected with Salmonella, including both groups preassociated with lactobacilli (ST, LA+ST, and LM+ST), showed increased expression of CD14 mRNA, but it was statistically significant in the LA+ST group only (Figure 3C). No statistically significant differences were found in LBP (Figure 3D). All Salmonella-infected groups (ST, LA+ST, and LM+ST) showed MyD88 mRNA statistically significant upregulation (Figure 3E). In contrast, no significant differences were found in another adaptor protein TRIF (Figure 3F). TLR2 mRNA was significantly upregulated in the Salmonella-infected groups (ST, LA+ST, and LM+ST) except the EcN+ST piglets (Figure 3G). TLR9 showed no significant changes in any group (Figure $3 \mathrm{H}$ ). RAGE was significantly upregulated in both groups colonized with the commensal L. amylovorus or L. mucosae (Figure 3I). 

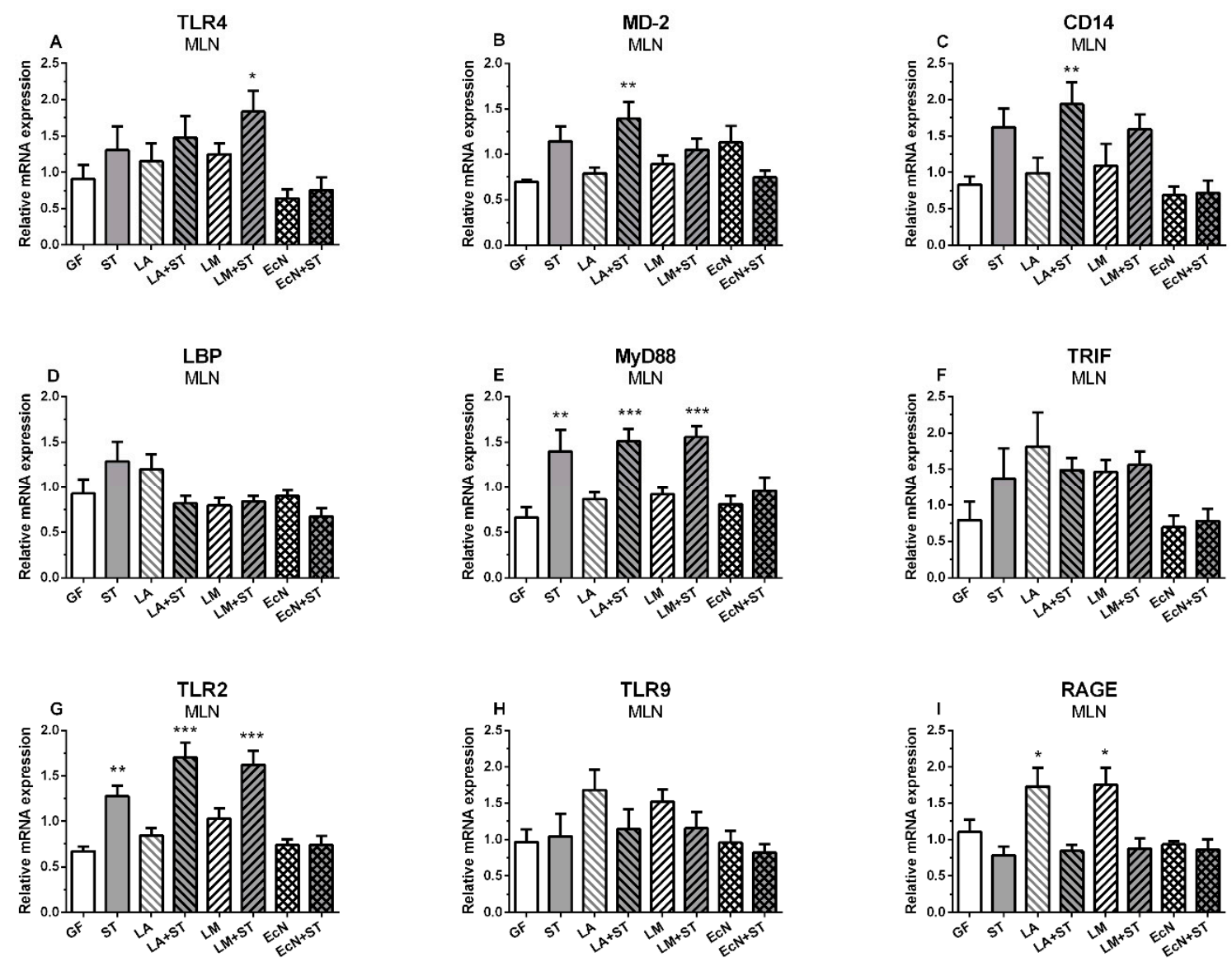

Figure 3. mRNA relative expression (fold change) of TLR4 and its related molecules, TLR2, TLR9, and RAGE in the MLN. TLR4 (A), MD-2 (B), CD-14 (C), LBP (D), MyD88 (E), TRIF (F), TLR2 (G), TLR9 $(\mathbf{H})$, and RAGE (I) are presented as mean + SEM. Differences between the control GF group and other groups were evaluated by one-way analysis of variance (ANOVA) with Dunnett's multiple comparison post-hoc test and depicted ${ }^{*} p<0.05,{ }^{* *} p<0.01,{ }^{* *} p<0.001 ; n=6$ for each group.

2.4. mRNA Relative Expressions of TLR4 and Its Related Molecules, TLR2, TLR9, and RAGE, in the Ileum, Colon, and MLN

The mRNA relative expressions of TLR4 and its related molecules, TLR2, TLR9, and RAGE in the ileum, colon, and MLN were summarized in Figure 4. 


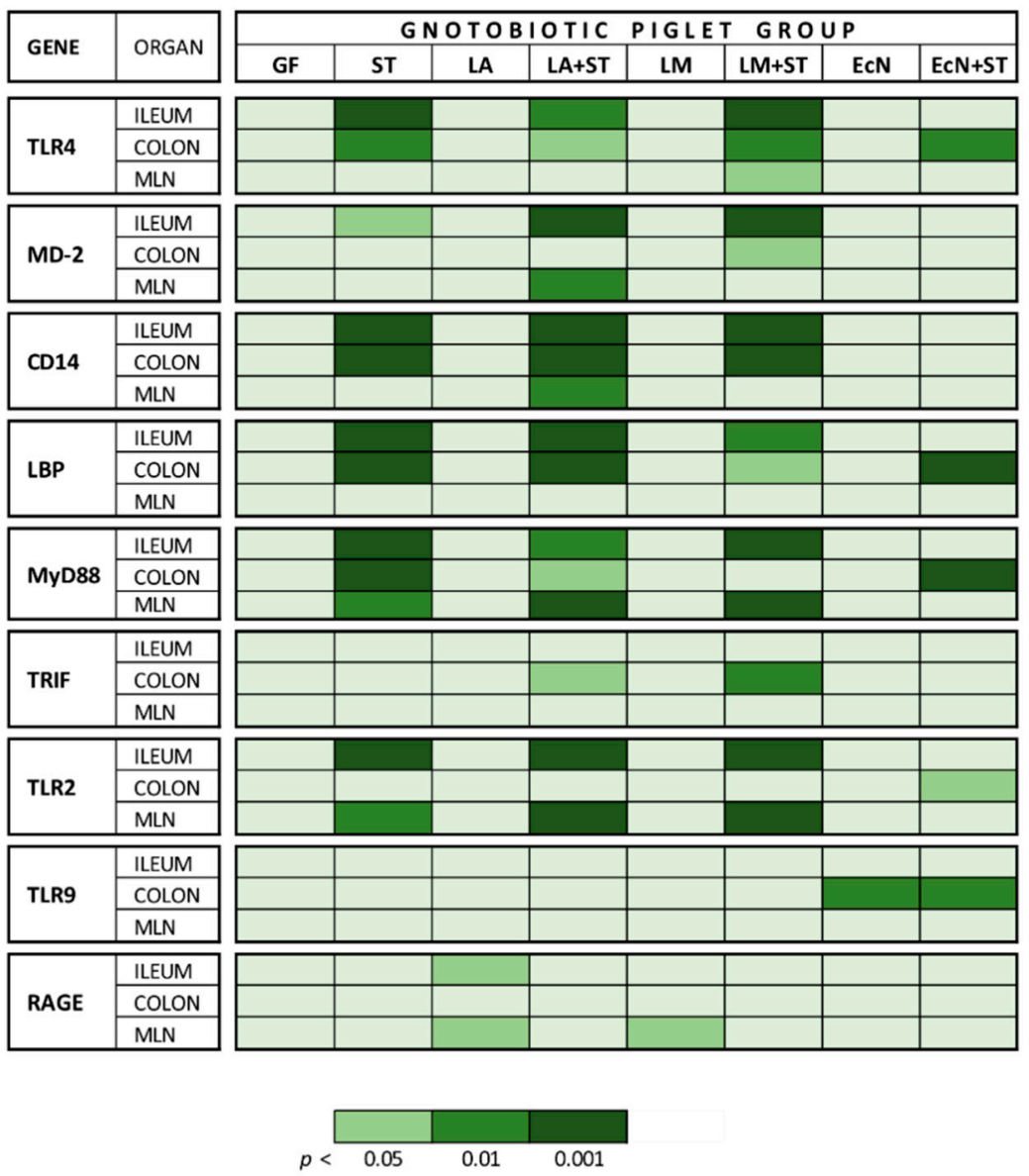

Figure 4. Summarized mRNA relative expression of TLR4 and its related molecules, TLR2, TLR9, and RAGE in the ileum, colon, and MLN. Differences between the control GF group and other groups were evaluated by one-way analysis of variance (ANOVA) with Dunnett's multiple comparison post-hoc test and depicted ${ }^{*} p<0.05,{ }^{* *} p<0.01,{ }^{* *} p<0.001 ; n=6$ for each group.

\section{5. mRNA Relative Expressions of HMGB1 in the Ileum, Colon, and MLN}

In the ileum, the relative mRNA of HMGB1 differed $(p<0.01)$ between the control GF and EcN groups only (Figure 5A). No significant differences were found in the colon (Figure 5B). mRNA HMGB1 expression in MLN (Figure 5C) was downregulated by Salmonella in the ST, LA+ST, and LM+ST groups, but did not reach the level of statistical difference compared to the GF control.
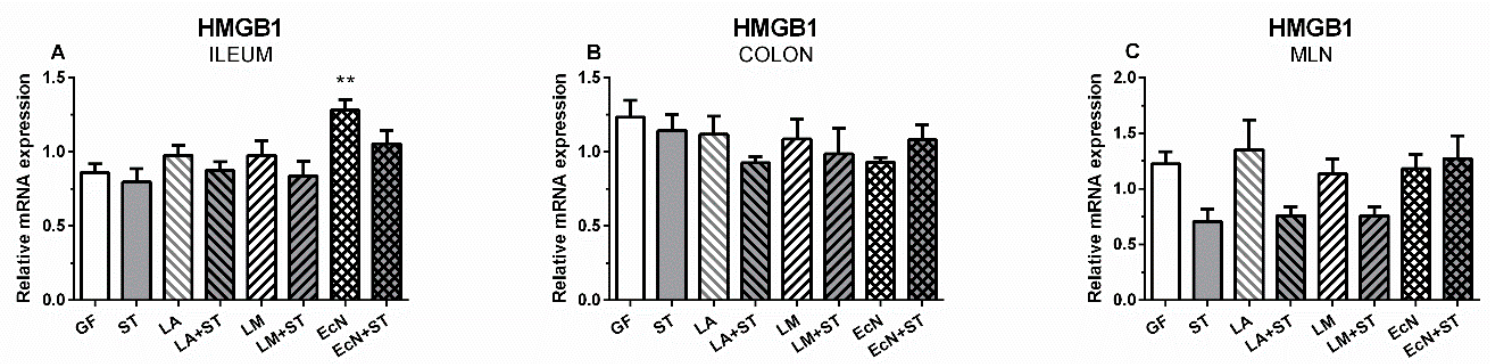

Figure 5. mRNA relative expression (fold change) of HMGB1 in the ileum, colon, and MLN of the gnotobiotic piglets. mRNA HMGB1 in the ileum (A), colon (B), and MLN (C) are presented as mean + SEM. Differences between the control GF group and other groups were evaluated by one-way analysis of variance (ANOVA) with Dunnett's multiple comparison post-hoc test and depicted * $p<0.05$, ** $p<0.01,{ }^{* * *} p<0.001 ; n=6$ for each group. 


\subsection{Cellular HMGB1 Protein in MLN}

HMGB1 protein localization in the MLN tissue of the control GF piglets and Salmonella-infected piglets (ST) were studied by immunofluorescence (Figure 6). HMGB1 was localized mainly in nuclei of MLN cells in the GF group (Figure 6A-C). In the case of the ST group, HMGB1 translocated from the nucleus, and it was located mainly in the cytoplasm (Figure 6D-F).
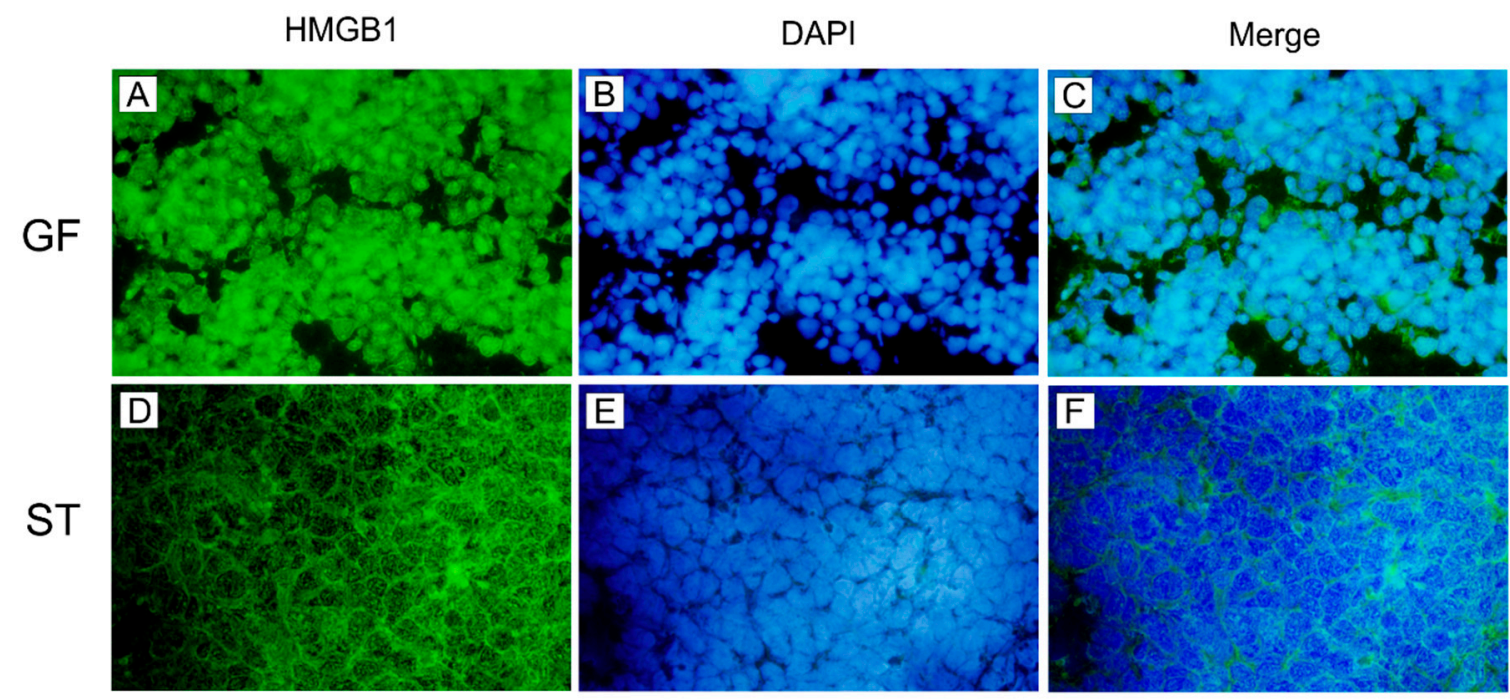

Figure 6. Immunofluorescence staining of HMGB1 in piglet MLN tissue. HMGB1 was stained green in the germ-free (GF; A) and Salmonella Typhimurium-infected piglets (ST; D) by Alexa 488. The nuclei were stained by blue in the GF (B) and ST piglets (E) by DAPI. HMGB1 was localized mainly in the nucleus in the GF piglets (C), but mainly in the cytoplasm in the ST group (F). Magnification is 1000×.

\subsection{Local and Systemic Levels of HMGB1}

Statistically significant increases of HMGB1 levels in the ileal lavages (Figure 7A) were found in the Salmonella-infected groups with ST, LA+ST, and LM+ST, with the exception of the piglets preliminary colonized with E. coli Nissle 1917 (EcN + ST). In plasma, much lower concentrations were detected compared to ileal contents and no statistically significant differences were found in any group (Figure 7B).
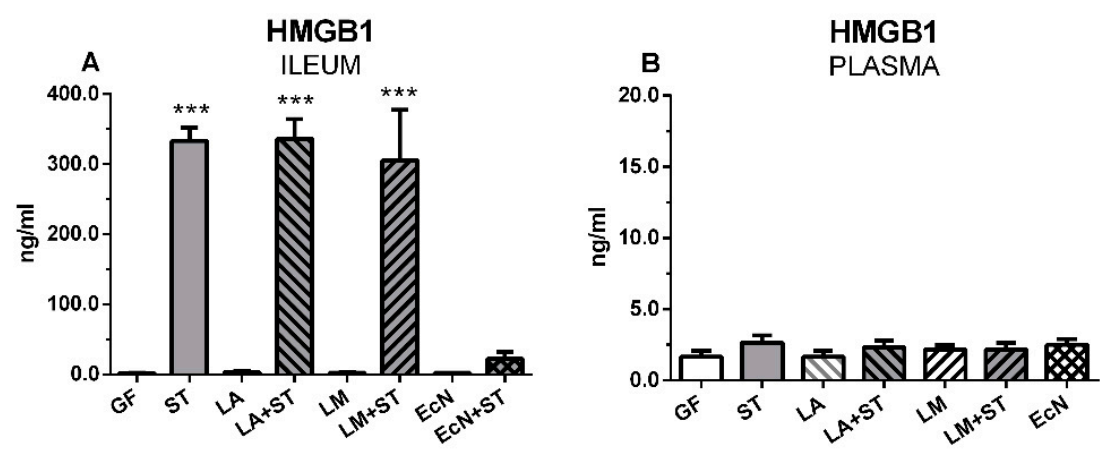

Figure 7. Local and systemic levels of HMGB1. The local HMGB1 levels in the ileum (A) and systemic HMGB1 levels in plasma (B) were measured in the gnotobiotic piglets by ELISA. Results are expressed as mean + SEM. Differences between the control GF group and other groups were evaluated by one-way analysis of variance (ANOVA) with Dunnett's multiple comparison post-hoc test and depicted ${ }^{*} p<0.05,{ }^{* *} p<0.01,{ }^{* * *} p<0.001 ; n=6$ for each group. 


\section{Discussion}

LPS (endotoxin) is highly immunomodulatory compound that can induce endotoxin shock [61,62], which is associated with excessive secretion of inflammatory cytokines called "cytokine storm" and can provoke lethal multiple organ dysfunction syndrome (MODS) [17,63]. While IL-1 and TNF- $\alpha$ are early induced inflammatory cytokines, HMGB1 that was the object of our interest is a late mediator of inflammatory reaction [11]. TLR4 is the common point of LPS and HMGB1 signaling pathways, because TLR4 is the receptor for both molecules [5,21] and HMGB1 potentiates the inflammatory effects of LPS [64]. The modulation of the TLR4 pathway can mitigate the injury from Gram-negative bacteria-induced sepsis. Signalling through TLR4 can be modulated by treatment with low-molecular weight natural and synthetic compounds [65], neutralizing antibodies [66-68], decoy soluble receptors [69], natural products and their derivatives [70], and probiotics [66,71,72]. The modulation can be targeted directly to TLR4 or its related molecules as co-receptors or adaptor proteins [73]. Released LPS [74,75] binds to LPS-binding protein (LBP) in serum, and the newly created LPS-LBP complex binds to CD14, which is expressed mainly on the cell membrane of phagocyting cells, but it also on other cell types, including enterocytes. The secreted MD-2 is associated with TLR4 and is essential for the expression of TLR4 and responsiveness of TLR4 to LPS [20,73].

Lactobacillus spp. are abundant in pig distal small intestine and colon [39,76]. Previously, selected lactobacilli were shown to modulate the TLR4 signaling in intestinal cell lines [72,77], intestinal explants [72], and conventional pigs [78]. We attempted to modulate the TLR4 signaling pathway in the gnotobiotic piglets using two commensal lactobacilli species, L. amylovorus and L. mucosae, and the probiotic E. coli Nissle 1917. We anticipated that the actions of two Lactobacillus strains would differ. It was reported that L. amylovorus modulation of TLR4 signaling prevented damage of an epithelial cell line and intestinal explants infected with enterotoxigenic E. coli K88 [72,79], whereas L. mucosae express a typical strain-specific mucus-binding protein (Mub), which mediates its binding to mucus in vitro [80]. E. coli Nissle 1917 has a semi-rough LPS (incompletely synthesized LPS chain) that determines its serum sensitivity and prevents the immunocompetent host from developing bacteremia from E. coli Nissle 1917 [81].

The main site of cross-talk between Salmonella Typhimurium and the host is in the distal ileum [29]. It is also the gastrointestinal segment with a plentiful population of aerotolerant bacteria in humans and animals, including lactobacilli and E. coli $[76,82]$. S. Typhimurium infection in gnotobiotic piglets up-regulated ileal mRNA expression of both members of TLR4/MD-2 complex and its co-receptor CD14 and LBP, with the exception the piglets previously associated with E. coli Nissle 1917 . This increase in TLR4 expression coincided with an upregulation of chemokine IL-8, pro-inflammatory cytokine TNF- $\alpha$, and regulatory cytokine IL-10 in S. Typhimurium-infected piglets, but not in the piglets associated with $L$, amylovorus, L. mucosae or E. coli Nissle 1917, as we described elsewhere [47]. Thus, previous colonization with E. coli Nissle 1917 suppressed the increased cytokine expression induced by $S$. Typhimurium infection.

It was shown that the avirulent rough LPS Salmonella enterica serovar Infantis and serovar Typhimurium, with an incompletely synthesized LPS chain, both protected gnotobiotic piglets against subsequent infection with virulent S. Typhimurium strains F98 [83] and LT2 [84], respectively. The protective effect may be due to local production of IL-8 and subsequent neutrophil recruitment $[83,84]$, actions on the TLR4 signaling pathway changes had not been previously reported. We speculate that rough LPS of both $S$. enterica serovars [83,84], as well as semi-rough LPS of E. coli Nissle 1917 [47], disrupted the TLR4/MD-2 signaling pathway and inhibited its ability to be triggered by the smooth LPS of the virulent $S$. Typhimurium. Therefore, they prevented the excessive detrimental production of the inflammatory cytokines [47]. All the bacteria mentioned above, which have incompletely synthesized LPS, induced physiological levels of IL-8 [47,83,84], which is necessary for the attraction and activation of neutrophils to the site of infection.

TLR4 is only one of the Toll-like receptors that use both MyD88 and TRIF adaptor molecule pathways [20,85]. MyD88 and TRIF are responsible for the activation of distinct signaling pathways, 
leading to the production of pro-inflammatory cytokines and type I interferons, respectively [5,73]. The LPS structure completeness influences the activation of the TLR4 signaling via MyD88 and TRIF pathways [85]. While MyD88 mRNA expression patterns followed those of TLR4, MD-2, and CD14 in the ileum, the expression of TRIF did not show any obvious relation to the infection with $S$. Typhimurium or association to other bacteria used before the challenge with $S$. Typhimurium. We concluded that the signaling in the Salmonella infection was via the MyD88 regulatory pathway.

The CD14 is well known about as co-receptor of TLR4, but much less is known its participation as co-receptor of TLR2 [86] and TLR9 [87]. The disruption of TLR signaling pathway induced by live virulent $E$. coli and E. coli-derived LPS in pigs by CD14 neutralization antibodies resulted in decreased levels of pro-inflammatory cytokines IL-1 $\beta$, IL-6, IL-8, and TNF- $\alpha$, and lower granulocyte activation in a pig model of sepsis [88]. TLR2 mRNA showed the same trend as the TLR4/MD-2 complex members in the ileum. In contrast, TLR9 mRNA expression was downregulated by $S$. Typhimurium in the ileum, but the downregulation was not statistically significant. It is possible that TLR2 and TLR9 play opposite roles during $S$. Typhimurium infection in the gnotobiotic piglets, as was found in mice [89]. Consistent with the TLR2 and TLR4, previous association with the probiotic E. coli Nissle 1917 inhibited the up-regulation of TLR9 mRNA expression after $S$. Typhimurium infection. Similarly, E. coli Nissle 1917 ameliorated dextran sulfate-induced colitis and decreased the pro-inflammatory cytokine response in wild-type mice, but not in TLR2 or TLR4 knockout mice [90], which supports E. coli Nissle 1917 immunomodulation of host TLR2 and TLR4 signaling. Concordantly with our findings of induced inflammatory cytokines reported elsewhere [47], 4-week-old weaned conventional piglets orally-infected with $S$. Typhimurium showed upregulation of TLR2 and TLR4 in the ileum that resulted in the expression of pro-inflammatory cytokine IL-1 $\beta$, IL- 6 , and TNF- $\alpha$ mRNA expressions 2 days post-infection [91].

The colon has a different histological structure and physiological role than the ileum [92]. The microbiota in the colon are composed of highly abundant anaerobes, and a lower proportion of lactobacilli and other aerotolerant bacteria compared to the ileum $[76,93]$. It was reported that different parts of the conventional piglet intestine infected with $S$. Typhimurium differed in their mRNA expression of inflammatory response-related genes, including TLRs [94]. In the colon, we found similar trends in TLR4, CD14, LBP, MyD88 as in the ileum, but not in the case of TLR2, which did not show any obvious trend. Both E. coli Nissle 1917-associated groups showed significantly increased TLR9 mRNA expression, which has not been previously reported.

The MLN are the main site of antigen presentation to combat bacteria that are translocated via M-cells, enterocytes, and dendritic cells or have penetrated autonomously through the disrupted intestinal barrier $[95,96]$. The translocated bacteria are destroyed immediately in the MLN, or their systemic spread is delayed. The processing of bacterial antigens or delays in systemic spread allows the establishment of a more efficient adaptive immune response [97,98]. TLR2 and TLR9 mRNA and proteins were expressed in the ileum, and MLN of newborn healthy piglets, with much higher expression in the MLN [99]. These findings support the ability of the piglets to respond to TLR ligands from birth.

In our experiments, gene expression of the receptors was lower in the MLN than either ileum or colon. In the MLN, expression of CD14, TLR2, and MyD88 all increased in response to Salmonella-infection, except in piglets previously innoculated with the probiotic E. coli. MD-2 enables TLR-2 to recognize LPS and enhances TLR2-mediated responses to both Gram-positive and Gram-negative bacterial, including peptidoglycan, lipoteichoic acid components, and LPS [100]. It seems that Gram-negative Salmonella was probably discriminated in the cooperation of MD-2, CD14, TLR4 but also TLR2. The TLR2 signaling confirmed increased MyD88 mRNA expression that is the adaptor molecule participating in the TLR2 signaling pathway [73].

In contrast to our results, four-week-old conventional piglets orally infected with $10^{8} \mathrm{CFU}$ S. Typhimurium serovar DT104 did not show any differences in CD14, TLR2, and MyD88 mRNA expression in the MLN two days post-infection [101]. RAGE mRNA was significantly increased 
in both groups of the piglets mono-associated with both commensal lactobacilli. However, RAGE is a multiligand receptor, including HMGB1, and exhibits various functions in physiological and pathological processes [5,102]. The reason of this upregulation is unknown, especially in the case of L. amylovorus, which was not found in the MLN, in contrast to L. mucosae that was found in a low number of CFUs in part of the piglets [47]. Even in the absence of live lactobacilli, there is possible stimulation by their processed PAMPs or DAMPs, such as as HMGB1 [5]. The elucidation of the commensal lactobacilli-induced upregulation in the MLN will need additional experiments.

HMGB1 is the endogenous ligand of TLR2, TLR4, and TLR9 [5]. It is an important inflammatory marker in the intestine in different pathologies. It was secreted into intestinal lumen either in enteric infections [103] or in inflammatory bowel diseases [104]. Necrotizing enterocolitis (NEC) that affects the immature intestine shows its devastating consequences partially due to the high expression of TLR4, which results in the induction of inflammatory cytokines and impairment of the epithelial barrier [105]. This illness shares some common characteristics with salmonellosis: it affects the ileum and colon, and neutrophils are recruited into the affected tissues $[106,107]$. The severity of the NEC in the rat model positively correlated with TLR4 and HMGB1 expression [108]. High levels of HMGB1 were also found in the intestine and plasma of E. coli O55-infected gnotobiotic piglets, but not in infected piglets that thrived [109]. Gnotobiotic piglets with highly immature intestine also showed recruitment of inflammatory cells in the S. Typhimurium-infected ileum [47]. Lastly, intestinal TLR4 mRNA upregulation and HMGB1 protein levels were increased in both TLR4 and HMGB1 proteins in the pig ileal tissue $120 \mathrm{hrs}$ after the infection with Clostridium perfringens type C [110]. Therefore, HMGB1 can serve as the marker of the damaged intestine.

Posttranslational modifications of HMGB1 determine its localization, migration, and biological activity. HMGB1 protein stays in the nucleus, but its hyperacetylation [13], hyperphosporylation [15], or mono-methylation [14] move HMGB1 from a nuclear localization to the cytoplasm [111]. After the exocytosis, the secreted HMGB1 may create complexes with LPS (similarly as LBP), transfer it to CD14, and initiate TLR4/MD-2-mediated inflammatory response and alongside increases HMGB1 magnitude [112]. We presented the micrographs of the mesenteric lymph nodes of the germ-free and $S$. Typhimurium-infected piglets only to simplify imagination about the HMGB1 localization and migration changes in the $S$. Typhimurium infection. HMGB1 in the mesenteric lymph nodes of the GF piglets was colocalized mainly with the nucleus, but it was spread into the cytoplasm in the Salmonella-infected ST group.

HMGB1 translocated from the nucleus to the cytoplasm and was secreted from cells; nevertheless, the expression of HMGB1 mRNA was not upregulated $16 \mathrm{hrs}$ after the stimulation [63]. The higher intestinal HMGB1 levels in the $S$. Typhimurium-infected groups suggest that secretion was in response to the infection. Lower intestinal HMGB1 levels in the intestine of infected piglets who has been inoculated with E. coli Nissle 1917 (EcN+ST) confirmed the anti-Salmonella properties of this probiotic bacteria [52]. The HMGB1 mRNA expression showed no significant differences among the piglet groups in our experiments. It indicates that increased intestinal HMGB1 levels in the Salmonella-infected piglets were not from de novo synthesized HMGB1.

In conclusion, HMGB1 mRNA transcription was not activated by the infection of the gnotobiotic piglets with $S$. Typhimurium within 24 hrs. This stability of the HMGB1 mRNA expression in all groups underlines the importance of HMGB1 for DNA transcription and other physiological cell functions and indicates that increased intestinal HMGB1 levels likely originated from formerly synthetized and actively secreted HMGB1 or passively released HMGB1 from damaged cells. However, the presence of HMGB1 protein in the intestinal lumen probably more attests spontaneous release after cellular damage than induced secretion as it was possible to suppress with the prior association of the gnotobiotic piglets with probiotic E. coli 1917. Future bacteria-driven immunomodulatory studies are needed to modify the signaling pathways and prevent or dampen the sepsis. 


\section{Materials and Methods}

\subsection{Ethics Statement}

All animal experiments were approved by the Animal Care and Use Committee of the Czech Academy of Sciences, protocol No. 117/2012, on 24 April 2012.

\subsection{Bacterial Suspensions}

All bacterial strains were from a collection of microorganisms at the Laboratory of Gnotobiology (Novy Hradek, Czech Republic). A probiotic E. coli Nissle 1917 (EcN) was originally donated to the collection by U. Sonnenborn (Ardeypharm, Herdecke, Germany) and Salmonella enterica serovar Typhimurium strain LT2 (ST) by O. Lüderitz (Max Planck Institute of Immunobiology, Freiburg, Germany). Commensal pig lactobacilli L. amylovorus strain P1 (LA) and L. mucosae strain P5 (LM) were isolated and characterized as we described elsewhere [47]. Fresh bacterial cultures were prepared by 16 hrs cultivation at $37^{\circ} \mathrm{C}$. EcN and ST grew on meat-peptone agar slopes (Oxoid, Basingstoke, UK) and lactobacilli in $10 \mathrm{~mL}$ MRS broth (Oxoid). Harvested cells were resuspended to an approximate $5 \times 10^{8} \mathrm{CFU} / \mathrm{m}$; in PBS.

Bacterial colonization of the gnotobiotic piglet intestine and translocation into liver, spleen, lungs, and blood we described elsewhere [47].

\subsection{Gnotobiotic Piglets}

Gnotobiotic piglets were obtained and bred in gnotobiotic isolators as described elsewhere [57]. Fifty-five piglets were divided to eight groups (Supplementary Figure S1): (i) GF (germ-free, $n=6$ ); (ii) ST (one-week-old GF piglets orally infected with $1 \times 10^{6} \mathrm{CFU}$ of $S$. Typhimurium for $24 \mathrm{~h}, n=7$ ); (iii) LA (GF orally colonized with $1 \times 10^{8}$ CFU of L. amylovorus $4 \mathrm{~h}$ after hysterectomy, $n=7$ ); (iv) LA+ST (one-week-old LA-colonized piglets orally infected with $1 \times 10^{6} \mathrm{CFU}$ of $S$. Typhimurium for $24 \mathrm{~h}, n=7$ ); (v) LM (GF orally colonized with $1 \times 10^{8}$ CFU of L. mucosae $4 \mathrm{~h}$ after hysterectomy, $n=7$ ); (vi) LM+ST (one-week-old LM-colonized piglets orally infected with $1 \times 10^{6} \mathrm{CFU}$ of $S$. Typhimurium for $24 \mathrm{~h}$, $n=7$ ); (vii) EcN (GF orally colonized with $1 \times 10^{8}$ CFU of E. coli Nissle $19174 \mathrm{~h}$ after hysterectomy, $n=7$ ), and (viii) EcN+ST (one-week-old EcN-colonized piglets orally infected with $1 \times 10^{6} \mathrm{CFU}$ of $S$. Typhimurium for $24 \mathrm{~h}, n=7$ ). Each piglet group was composed of three independent hysterectomies and bred separately from other groups in a fiberglass gnotobiotic isolators. The bacteria were supplied in $5 \mathrm{~mL}$ of a milk diet, and the control GF piglets received $5 \mathrm{~mL}$ of milk without any bacteria. At the end of the experiment, the piglets were humanely euthanized by exsanguination via cardiac puncture under isoflurane anesthesia.

\subsection{Total RNA Isolation, Reverse Transcription}

Total RNA from the terminal ileum, transverse colon, and mesenteric lymph nodes was isolated and transcribed as described elsewhere [57]. Approximately $10 \mathrm{mg}$ of the tissue stored in RNAlater (Qiagen, Hilden, Germany) at $-20^{\circ} \mathrm{C}$ were moved to RLT buffer of the RNeasy Plus Mini kit (Qiagen) with zirconia beads (BioSpec Products, Bartlesville, OK). The tissue was homogenized in TissueLyser LT beadbeater (Qiagen). The next steps followed the manufacturer's instructions. Five hundred ng of the total RNA $\left(\mathrm{A}_{260} / \mathrm{A}_{280} \geq 2.0\right.$ as measured in $10 \mathrm{mM}$ Tris- $\mathrm{HCl}$ buffer $\left.\mathrm{pH} 7.5\right)$ were reverse transcribed by QuantiTect Reverse Transcription kit (Qiagen) according to manufacturer's instructions. $20 \mu \mathrm{L}$ of the synthesized cDNA was 1/10 diluted by PCR quality water (Life Technologies, Carlsbad, CA), and these PCR templates were stored at $-25^{\circ} \mathrm{C}$ until the following real-time PCR.

\subsection{Real-Time PCR}

$2 \mu \mathrm{L}$ of the PCR template was added to $18 \mu \mathrm{L}$ of the FastStart Universal Probe Master (Roche Diagnostics) containing 100 nM LNA (lock nucleic acid) probe (Universal ProbeLibrary; 
Roche Diagnostics) and $500 \mathrm{nM}$ each of the forward and reverse primers (Generi-Biotech, Hradec Kralove, Czech Republic)-Table 1.

Table 1. LNA probe-based Real-Time PCR systems.

\begin{tabular}{|c|c|c|c|}
\hline Gene & $5^{\prime}$-Forward primer-3' & $5^{\prime}$-Reverse primer-3' & \#LNA Probe \\
\hline BACT $^{1}$ & TCCCTGGAGAAGAGCTACGA & AAGAGCGCCTCTGGACAC & 9 \\
\hline CYPA $^{2}$ & CCTGAAGCATACGGGTCCT & AAAGACCACATGTTTGCCATC & 48 \\
\hline HMGB1 & AGGAGAGCATCCTGGCCTA & ATCTGCAGCGGTGTTATTCC & 9 \\
\hline TLR $4^{3}$ & CCATGGCCTTTCTCTCCTG & TCAGCTCCATGCATTGGTAA & 33 \\
\hline $\mathrm{MD}-2^{4}$ & GCTCTGAAGGGAGAGACTGTG & TTGTCCCGGAGAAAATCGTA & 12 \\
\hline CD14 ${ }^{5}$ & TCTCACCACCCTGGACCTAT & AACTTGCGCGGACAGAGA & 23 \\
\hline $\mathrm{LBP}^{6}$ & ACTAGACGGCTCCTTTGACG & GCCCAGGAGAAGATTGACTG & 9 \\
\hline TLR2 $^{3}$ & CTGCTCCTGTGACTTCCTGTC & AGGTAGTTCTCCGGCCAGTC & 40 \\
\hline TLR9 $^{3}$ & CAATGACATCCATAGCCGAGT & CGTTGCCGCTAAAGTCCA & 3 \\
\hline MyD88 7 & GCAGCTGGAACAGACCAACT & GTGCCAGGCAGGACATCT & 41 \\
\hline TRIF $^{8}$ & ATCTCCCTGGAGGCACTGA & GCTGTCTACACCAGCCCACT & 9 \\
\hline
\end{tabular}

${ }^{1} \beta$-actin, ${ }^{2}$ cyclophylin $\mathrm{A},{ }^{3}$ Toll-like receptor, ${ }^{4}$ myeloid differentiation protein $2,{ }^{5}$ cluster of differentiation 14 , ${ }^{6}$ lipopolysaccharide binding protein, 7 myeloid differentiation factor 88,8 TIR-domain-containing adapter-inducing interferon- $\beta$.

Ten minutes' initial heating at $95^{\circ} \mathrm{C}$ was followed by 45 cycles at $95^{\circ} \mathrm{C}$ for $15 \mathrm{~s}$ and $60{ }^{\circ} \mathrm{C}$ for $60 \mathrm{~s}$ were incubated and measured in duplicates on an iQ cycler with iQ5 Optical System Software 1.0 (Bio-Rad, Hercules, CA, USA). Cq for genes of the interest was normalized to Cq for $\beta$-actin and cyclophilin A reference genes and the relative mRNA fold change expressions of the genes of interest were calculated by $2^{-\Delta C T}$ method [113] by GenEx 6.1 software (MultiD Analyses AB, Gothenburg, Sweden).

\subsection{Immunofluorescent Detection of HMGB1 in Mesenteric Lymph Nodes}

Mesenteric lymph nodes were embedded in Tissue-Tek (Sakura, Tokyo, Japan), snap-frozen in isopentane cooled in liquid nitrogen vapor, and stored at $-70{ }^{\circ} \mathrm{C} .5-\mu \mathrm{m}$ acetone-fixed cryosections on SuperFrost/Plus slides (Thermo Fisher Scientific, Darmstadt, Germany) were kept at $-40{ }^{\circ} \mathrm{C}$ until labeling. The sections were incubated with $10 \%$ normal rabbit serum (Life Technologies, Carlsbad, CA, USA) in a humid chamber for one $h$ at RT. Labeling by anti-HMGB1 rabbit polyclonal antibodies (Novus Biologicals, Centennial, CO, USA) was performed overnight at $4{ }^{\circ} \mathrm{C}$. The sections were incubated with secondary antibody, Alexa Fluor 488 goat anti-rabbit IgG (Life Technologies), for $2 \mathrm{~h}$ at RT. The sections were subsequently embedded in ProLong Gold Antifade Reagent (Life Technologies) and examined under an Olympus BX 40 microscope with a Olympus Camedia C-2000 digital camera (Olympus, Tokyo, Japan). Control sections without primary antibody were treated in the same way. The colocalization of HMGB1 and nuclei was analyzed by ImageJ software [114].

\subsection{Local and Systemic HMGB1 Levels}

$40 \mathrm{~cm}$ of the distal small intestine (labelled here as ileum) was filled with $2 \mathrm{~mL}$ of Dulbecco's Phosphate Buffered Saline (DPBS), gently kneaded, and irrigated. The obtained intestinal lavages were spun at $2500 \times \mathrm{g}$ for $30 \mathrm{~min}$ at $8{ }^{\circ} \mathrm{C}$, and supernatants were filtered through a $0.2 \mu \mathrm{m}$ nitrocellulose filter (Sartorius, Goettingen, Germany). A citrated blood sample was spun at $1200 \times g$ for $10 \mathrm{~min}$ at $8{ }^{\circ} \mathrm{C}$. A protease inhibitor cocktail (Roche Diagnostics, Manheim, Germany) was added to the lavage supernatants and plasma. Both supernatants and plasma were aliquoted, immediately frozen, and stored at $-45^{\circ} \mathrm{C}$. The HMGB1 levels were quantified in duplicates by ELISA kit (IBL International, Hamburg, Germany) according to manufacturer's instructions. Optical densities were measured at $450 \mathrm{~nm}$ and $620 \mathrm{~nm}$ with an Infinite M200 Microplate reader and the results were evaluated with Magellan 6.3 software (Tecan, Grödig, Austria). 


\subsection{Statistical Analysis}

Differences of the groups to the control GF group in parameters with normal distribution were evaluated with one-way ANOVA with Dunnet's multiple comparisons post-hoc test. The statistical evaluations were performed at $p<0.05,{ }^{* *} p<0.01$, and ${ }^{* * *} p<0.001$ by GraphPad 6 software (GraphPad Software, La Jolla, CA, USA) and statistical significances of differences depicted in figures by asterisks.

Supplementary Materials: Supplementary materials can be found at http://www.mdpi.com/1422-0067/20/24/6294/s1.

Author Contributions: Conceptualization, I.S. (Igor Splichal), S.M.D., and A.S.; methodology, I.S. (Igor Splichal), V.J., I.S. (Iva Splichalova), H.S., E.V., V.N.B., E.S., M.S., J.K., and A.S.; validation, I.S. (Igor Splichal) and A.S.; formal analysis, I.S. (Igor Splichal), V.J., I.S. (Iva Splichalova), E.V., V.N.B., M.S., J.K., E.S., and A.S.; investigation, I.S. (Igor Splichal), V.J., I.S. (Iva Splichalova), H.S., and A.S.; resources, I.S. (Igor Splichal), S.M.D., and E.V.; data curation, I.S. (Igor Splichal), E.V., and A.S.; writing—original draft preparation, I.S. (Igor Splichal), I.S. (Iva Splichalova), and A.S.; writing-review and editing, I.S. (Igor Splichal), S.M.D., E.V., and A.S.; supervision, I.S. (Igor Splichal) and A.S.; project administration, I.S. (Igor Splichal), S.M.D., and E.V.; funding acquisition, I.S. (Igor Splichal), S.M.D., and E.V.

Funding: This work was funded by grant 13-08803S of the Czech Science Foundation and the Institutional Research concept RVO 61388971 of the Institute of Microbiology of the Czech Academy of Sciences and European Regional Development Fund-Project NutRisk Centre, No. CZ.02.1.01/0.0/0.0/16_019/0000845. V.J. was supported by grant GAUK 1368217 of the Grant Agency of the Charles University. S.M.D was supported by NIH grant RO1 DK107561.

Acknowledgments: We are grateful to Jana Machova, Hana Sychrovska, and Jarmila Jarkovska for animal care, microbiological work, and a procession of samples. The special thanks is given to professor V. Rada from the University of Life Sciences in Prague for fruitful discussions.

Conflicts of Interest: The authors declare no conflict of interest.

\section{Abbreviations}

$\begin{array}{ll}2^{-\Delta C T} & \text { Comparative } \mathrm{C}_{\mathrm{T}} \text { method } \\ \text { BACT } & \beta \text {-actin } \\ \mathrm{C}_{\mathrm{q}} & \text { Cycle of quantification } \\ \mathrm{C}_{\mathrm{T}} & \text { Treshold cycle } \\ \text { CYPA } & \text { Cyclophylin A } \\ \text { DAMPs } & \text { Damage-Associated Molecular Patterns } \\ \text { DAPI } & 4^{\prime}, 6 \text {-diamidino-2-phenylindole } \\ \text { EcN } & \text { Escherichia coli Nissle 1917 } \\ \text { ELISA } & \text { Enzyme Linked Immuno Sorbent Assay } \\ \text { GF } & \text { Germ-free } \\ \text { GIT } & \text { Gastrointestinal tract } \\ \text { HMGB1 } & \text { High mobility group box 1 } \\ \text { IFN } & \text { Interferon } \\ \text { IL } & \text { Interleukin } \\ \text { LA } & \text { Lactobacillus amylovorus } \\ \text { LBP } & \text { Lipopolysaccharide binding protein } \\ \text { LM } & \text { Lactobacillus mucosae } \\ \text { LNA } & \text { Locked nucleic acid } \\ \text { LT2 } & \text { Salmonella Typhimurium strain LT2 } \\ \text { MD-2 } & \text { Myeloid differentiation factor 2 } \\ \text { MRS } & \text { De Man, Rogosa, and Sharpe } \\ \text { MyD88 } & \text { Myeloid differentiation primary response 88 } \\ \text { NEC } & \text { Necrotizing enterocolitis } \\ \text { NF- } k \text { B } & \text { Nuclear factor kappa B } \\ \text { NTS } & \text { Non-typhoidal Salmonellae } \\ \text { PAMPs } & \text { Pathogen-Associated Molecular Patterns } \\ & \\ & \end{array}$




$\begin{array}{ll}\text { PRRs } & \text { Pathogen Recognition Receptors } \\ \text { RAGE } & \text { Receptor for Advanced Glycation End } \\ \text { RT-qPCR } & \text { Real-Time quantitative Polymerase Chain Reaction } \\ \text { ST } & \text { Salmonella Typhimurium } \\ \text { TLR } & \text { Toll-like Receptor } \\ \text { TNF } & \text { Tumor Necrosis Factor } \\ \text { TRIF } & \text { TIR domain-containing adaptor inducing IFN- } \beta\end{array}$

\section{References}

1. Dumitriu, I.E.; Baruah, P.; Manfredi, A.A.; Bianchi, M.E.; Rovere-Querini, P. HMGB1: Guiding immunity from within. Trends Immunol. 2005, 26, 381-387. [CrossRef] [PubMed]

2. Griess, E.A.; Rensing, S.A.; Grasser, K.D.; Maier, U.G.; Feix, G. Phylogenetic relationships of HMG box DNA-binding domains. J. Mol. Evol. 1993, 37, 204-210. [CrossRef] [PubMed]

3. Bianchi, M.E.; Crippa, M.P.; Manfredi, A.A.; Mezzapelle, R.; Rovere, Q.P.; Venereau, E. High-mobility group box 1 protein orchestrates responses to tissue damage via inflammation, innate and adaptive immunity, and tissue repair. Immunol. Rev. 2017, 280, 74-82. [CrossRef] [PubMed]

4. Calogero, S.; Grassi, F.; Aguzzi, A.; Voigtlander, T.; Ferrier, P.; Ferrari, S.; Bianchi, M.E. The lack of chromosomal protein Hmg1 does not disrupt cell growth but causes lethal hypoglycaemia in newborn mice. Nat. Genet. 1999, 22, 276-280. [CrossRef]

5. Chen, G.Y.; Nunez, G. Sterile inflammation: Sensing and reacting to damage. Nat. Rev. Immunol. 2010, 10, 826-837. [CrossRef]

6. Rider, P.; Voronov, E.; Dinarello, C.A.; Apte, R.N.; Cohen, I. Alarmins: Feel the stress. J. Immunol. 2017, 198, 1395-1402. [CrossRef]

7. Deng, M.; Scott, M.J.; Fan, J.; Billiar, T.R. Location is the key to function: HMGB1 in sepsis and trauma-induced inflammation. J. Leukoc. Biol. 2019. [CrossRef]

8. Bertheloot, D.; Latz, E. HMGB1, IL-1alpha, IL-33 and S100 proteins: Dual-function alarmins. Cell Mol. Immunol. 2017, 14, 43-64. [CrossRef]

9. Dogi, C.A.; Galdeano, C.M.; Perdigon, G. Gut immune stimulation by non pathogenic Gram(+) and Gram(-) bacteria. Comparison with a probiotic strain. Cytokine 2008, 41, 223-231. [CrossRef]

10. Surbatovic, M.; Popovic, N.; Vojvodic, D.; Milosevic, I.; Acimovic, G.; Stojicic, M.; Veljovic, M.; Jevdjic, J.; Djordjevic, D.; Radakovic, S. Cytokine profile in severe Gram-positive and Gram-negative abdominal sepsis. Sci Rep. 2015, 5, 11355. [CrossRef]

11. Cinel, I.; Opal, S.M. Molecular biology of inflammation and sepsis: A primer. Crit. Care Med. 2009, 37, 291-304. [CrossRef] [PubMed]

12. Yu, H.; Qi, Z.; Zhao, L.; Shao, R.; Fang, Y.; Li, C. Prognostic value of dynamic monitoring of cellular immunity and HMGB1 in severe sepsis: Delayed chronic inflammation may be the leading cause of death in late severe sepsis. Clin. Lab. 2016, 62, 2379-2385. [CrossRef] [PubMed]

13. Bonaldi, T.; Talamo, F.; Scaffidi, P.; Ferrera, D.; Porto, A.; Bachi, A.; Rubartelli, A.; Agresti, A.; Bianchi, M.E. Monocytic cells hyperacetylate chromatin protein HMGB1 to redirect it towards secretion. EMBO J. 2003, 22, 5551-5560. [CrossRef] [PubMed]

14. Ito, I.; Fukazawa, J.; Yoshida, M. Post-translational methylation of high mobility group box 1 (HMGB1) causes its cytoplasmic localization in neutrophils. J. Biol. Chem. 2007, 282, 16336-16344. [CrossRef] [PubMed]

15. Youn, J.H.; Shin, J.S. Nucleocytoplasmic shuttling of HMGB1 is regulated by phosphorylation that redirects it toward secretion. J. Immunol. 2006, 177, 7889-7897. [CrossRef]

16. Scaffidi, P.; Misteli, T.; Bianchi, M.E. Release of chromatin protein HMGB1 by necrotic cells triggers inflammation. Nature 2002, 418, 191-195. [CrossRef] [PubMed]

17. Wang, H.; Ma, S. The cytokine storm and factors determining the sequence and severity of organ dysfunction in multiple organ dysfunction syndrome. Am. J. Emerg. Med. 2008, 26, 711-715. [CrossRef]

18. Janeway, C.A., Jr. Approaching the asymptote? Evolution and revolution in immunology. Cold Spring Harb. Symp. Quant. Biol. 1989, 54, 1-13. [CrossRef]

19. Kawai, T.; Akira, S. The role of pattern-recognition receptors in innate immunity: Update on Toll-like receptors. Nat. Immunol. 2010, 11, 373-384. [CrossRef] 
20. Cao, X. Self-regulation and cross-regulation of pattern-recognition receptor signalling in health and disease. Nat. Rev. Immunol. 2016, 16, 35-50. [CrossRef]

21. Takeuchi, O.; Akira, S. Pattern recognition receptors and inflammation. Cell 2010, 140, 805-820. [CrossRef] [PubMed]

22. Vourc'h, M.; Roquilly, A.; Asehnoune, K. Trauma-Induced Damage-Associated Molecular Patterns-Mediated Remote Organ Injury and Immunosuppression in the Acutely Ill Patient. Front. Immunol. 2018, 9, 1330. [CrossRef] [PubMed]

23. Deutschman, C.S.; Tracey, K.J. Sepsis: Current dogma and new perspectives. Immunity 2014, 40, 463-475. [CrossRef] [PubMed]

24. Bone, R.C.; Balk, R.A.; Cerra, F.B.; Dellinger, R.P.; Fein, A.M.; Knaus, W.A.; Schein, R.M.; Sibbald, W.J. Definitions for sepsis and organ failure and guidelines for the use of innovative therapies in sepsis. The ACCP/SCCM Consensus Conference Committee. American College of Chest Physicians/Society of Critical Care Medicine. Chest 1992, 101, 1644-1655. [CrossRef] [PubMed]

25. Singer, M.; Deutschman, C.S.; Seymour, C.W.; Shankar-Hari, M.; Annane, D.; Bauer, M.; Bellomo, R.; Bernard, G.R.; Chiche, J.D.; Coopersmith, C.M.; et al. The Third international consensus definitions for sepsis and septic shock (sepsis-3). JAMA 2016, 315, 801-810. [CrossRef] [PubMed]

26. Lunney, J.K. Advances in swine biomedical model genomics. Int. J. Biol. Sci. 2007, 3, 179-184. [CrossRef] [PubMed]

27. Xiao, L.; Estelle, J.; Kiilerich, P.; Ramayo-Caldas, Y.; Xia, Z.; Feng, Q.; Liang, S.; Pedersen, A.O.; Kjeldsen, N.J.; Liu, C.; et al. A reference gene catalogue of the pig gut microbiome. Nat. Microbiol. 2016, 1, 16161. [CrossRef]

28. Meurens, F.; Summerfield, A.; Nauwynck, H.; Saif, L.; Gerdts, V. The pig: A model for human infectious diseases. Trends Microbiol. 2012, 20, 50-57. [CrossRef]

29. Zhang, Q.; Widmer, G.; Tzipori, S. A pig model of the human gastrointestinal tract. Gut Microbes 2013, 4, 193-200. [CrossRef]

30. Kaiser, P.; Hardt, W.D. Salmonella typhimurium diarrhea: Switching the mucosal epithelium from homeostasis to defense. Curr. Opin. Immunol. 2011, 23, 456-463. [CrossRef]

31. Barthel, M.; Hapfelmeier, S.; Quintanilla-Martinez, L.; Kremer, M.; Rohde, M.; Hogardt, M.; Pfeffer, K.; Russmann, H.; Hardt, W.D. Pretreatment of mice with streptomycin provides a Salmonella enterica serovar Typhimurium colitis model that allows analysis of both pathogen and host. Infect. Immun. 2003, 71, 2839-2858. [CrossRef] [PubMed]

32. Wen, S.C.; Best, E.; Nourse, C. Non-typhoidal Salmonella infections in children: Review of literature and recommendations for management. J. Paediatr. Child Health 2017, 53, 936-941. [CrossRef] [PubMed]

33. Crump, J.A.; Sjolund-Karlsson, M.; Gordon, M.A.; Parry, C.M. Epidemiology, clinical presentation, laboratory diagnosis, antimicrobial resistance, and antimicrobial management of invasive Salmonella infections. Clin. Microbiol. Rev. 2015, 28, 901-937. [CrossRef] [PubMed]

34. European Food Safety Authority and European Centre for Disease Prevention and Control The European Union summary report on antimicrobial resistance in zoonotic and indicator bacteria from humans, animals and food in 2017. EPSA J. 2019, 17, 5598. [CrossRef]

35. Wang, X.; Biswas, S.; Paudyal, N.; Pan, H.; Li, X.; Fang, W.; Yue, M. Antibiotic resistance in Salmonella Typhimurium isolates recovered from the food chain through National Antimicrobial Resistance Monitoring System between 1996 and 2016. Front. Microbiol. 2019, 10, 985. [CrossRef]

36. Liu, Y.; Espinosa, C.D.; Abelilla, J.J.; Casas, G.A.; Lagos, L.V.; Lee, S.A.; Kwon, W.B.; Mathai, J.K.; Navarro, D.M.D.L.; Jaworski, N.W.; et al. Non-antibiotic feed additives in diets for pigs: A review. Anim. Nutr. 2018, 4, 113-125. [CrossRef]

37. Gajdacs, M. The Concept of an ideal antibiotic: Implications for drug design. Molecules 2019, $24,892$. [CrossRef]

38. Yang, J.; Qian, K.; Wang, C.; Wu, Y. Roles of probiotic Lactobacilli inclusion in helping piglets establish healthy intestinal inter-environment for pathogen defense. Probiotics Antimicrob. Proteins 2018, 10, 243-250. [CrossRef]

39. Crespo-Piazuelo, D.; Estelle, J.; Revilla, M.; Criado-Mesas, L.; Ramayo-Caldas, Y.; Ovilo, C.; Fernandez, A.I.; Ballester, M.; Folch, J.M. Characterization of bacterial microbiota compositions along the intestinal tract in pigs and their interactions and functions. Sci. Rep. 2018, 8, 12727. [CrossRef] 
40. Backhed, F.; Roswall, J.; Peng, Y.; Feng, Q.; Jia, H.; Kovatcheva-Datchary, P.; Li, Y.; Xia, Y.; Xie, H.; Zhong, H.; et al. Dynamics and stabilization of the human gut microbiome during the first year of life. Cell Host Microbe 2015, 17, 690-703. [CrossRef]

41. van Baarlen, P.; Wells, J.M.; Kleerebezem, M. Regulation of intestinal homeostasis and immunity with probiotic lactobacilli. Trends Immunol. 2013, 34, 208-215. [CrossRef] [PubMed]

42. Aroutcheva, A.; Gariti, D.; Simon, M.; Shott, S.; Faro, J.; Simoes, J.A.; Gurguis, A.; Faro, S. Defense factors of vaginal lactobacilli. Am. J. Obstet. Gynecol. 2001, 185, 375-379. [CrossRef] [PubMed]

43. Castro-Gonzalez, J.M.; Castro, P.; Sandoval, H.; Castro-Sandoval, D. Probiotic lactobacilli precautions. Front. Microbiol. 2019, 10, 375. [CrossRef] [PubMed]

44. Gajdacs, M.; Spengler, G.; Urban, E. Identification and antimicrobial susceptibility testing of anaerobic bacteria: Rubik's cube of clinical microbiology? Antibiotics 2017, 6, 25. [CrossRef] [PubMed]

45. Lievin-Le Moal, V.; Servin, A.L. Anti-infective activities of lactobacillus strains in the human intestinal microbiota: From probiotics to gastrointestinal anti-infectious biotherapeutic agents. Clin. Microbiol. Rev. 2014, 27, 167-199. [CrossRef] [PubMed]

46. Halder, D.; Mandal, M.; Chatterjee, S.S.; Pal, N.K.; Mandal, S. Indigenous probiotic lactobacillus isolates presenting antibiotic like activity against human pathogenic bacteria. Biomedicines 2017, 5, 31. [CrossRef] [PubMed]

47. Splichal, I.; Donovan, S.M.; Splichalova, Z.; Neuzil Bunesova, V.; Vlkova, E.; Jenistova, V.; Killer, J.; Svejstil, R.; Skrivanova, E.; Splichalova, A. Colonization of germ-free piglets with commensal Lactobacillus amylovorus, Lactobacillus mucosae, and probiotic E. coli Nissle 1917 and their interference with Salmonella Typhimurium. Microorganisms 2019, 7, 273. [CrossRef]

48. Robins-Browne, R.M.; Holt, K.E.; Ingle, D.J.; Hocking, D.M.; Yang, J.; Tauschek, M. Are Escherichia coli pathotypes still relevant in the era of whole-genome sequencing? Front. Cell Infect. Microbiol. 2016, 6, 141. [CrossRef]

49. Wassenaar, T.M. Insights from 100 years of research with probiotic E. coli. Eur. J. Microbiol. Immunol. 2016, 6, 147-161. [CrossRef]

50. Henker, J.; Laass, M.; Blokhin, B.M.; Bolbot, Y.K.; Maydannik, V.G.; Elze, M.; Wolff, C.; Schulze, J. The probiotic Escherichia coli strain Nissle $1917(\mathrm{EcN})$ stops acute diarrhoea in infants and toddlers. Eur. J. Pediatr. 2007, 166, 311-318. [CrossRef]

51. Schroeder, B.; Duncker, S.; Barth, S.; Bauerfeind, R.; Gruber, A.D.; Deppenmeier, S.; Breves, G. Preventive effects of the probiotic Escherichia coli strain Nissle 1917 on acute secretory diarrhea in a pig model of intestinal infection. Dig. Dis. Sci. 2006, 51, 724-731. [CrossRef] [PubMed]

52. Trebichavsky, I.; Splichal, I.; Rada, V.; Splichalova, A. Modulation of natural immunity in the gut by Escherichia coli strain Nissle 1917. Nutr. Rev. 2010, 68, 459-464. [CrossRef] [PubMed]

53. Mooser, C.; Gomez de, A.M.; Ganal-Vonarburg, S.C. Standardization in host-microbiota interaction studies: Challenges, gnotobiology as a tool, and perspective. Curr. Opin. Microbiol. 2018, 44, 50-60. [CrossRef] [PubMed]

54. Stecher, B.; Hardt, W.D. Mechanisms controlling pathogen colonization of the gut. Curr. Opin. Microbiol. 2011, 14, 82-91. [CrossRef] [PubMed]

55. Tremaroli, V.; Backhed, F. Functional interactions between the gut microbiota and host metabolism. Nature 2012, 489, 242-249. [CrossRef] [PubMed]

56. Salmon, H.; Berri, M.; Gerdts, V.; Meurens, F. Humoral and cellular factors of maternal immunity in swine. Dev. Comp. Immunol. 2009, 33, 384-393. [CrossRef] [PubMed]

57. Splichalova, A.; Slavikova, V.; Splichalova, Z.; Splichal, I. Preterm life in sterile conditions: A study on preterm, germ-free piglets. Front. Immunol. 2018, 9, 220. [CrossRef]

58. McClelland, M.; Sanderson, K.E.; Spieth, J.; Clifton, S.W.; Latreille, P.; Courtney, L.; Porwollik, S.; Ali, J.; Dante, M.; Du, F.; et al. Complete genome sequence of Salmonella enterica serovar Typhimurium LT2. Nature 2001, 413, 852-856. [CrossRef]

59. Clarke, R.C.; Gyles, C.L. Virulence of wild and mutant strains of Salmonella typhimurium in ligated intestinal segments of calves, pigs, and rabbits. Am. J. Vet. Res. 1987, 48, 504-510.

60. Splichalova, A.; Jenistova, V.; Splichalova, Z.; Splichal, I. Colonization of preterm gnotobiotic piglets with probiotic Lactobacillus rhamnosus GG and its interference with Salmonella Typhimurium. Clin. Exp. Immunol. 2019, 195, 381-394. [CrossRef] 
61. Morris, M.C.; Gilliam, E.A.; Li, L. Innate immune programing by endotoxin and its pathological consequences. Front. Immunol. 2014, 5, 680. [CrossRef] [PubMed]

62. Munford, R.S. Sensing gram-negative bacterial lipopolysaccharides: A human disease determinant? Infect. Immun. 2008, 76, 454-465. [CrossRef] [PubMed]

63. Wang, H.; Bloom, O.; Zhang, M.; Vishnubhakat, J.M.; Ombrellino, M.; Che, J.; Frazier, A.; Yang, H.; Ivanova, S.; Borovikova, L.; et al. HMG-1 as a late mediator of endotoxin lethality in mice. Science 1999, 285, 248-251. [CrossRef] [PubMed]

64. Qin, Y.H.; Dai, S.M.; Tang, G.S.; Zhang, J.; Ren, D.; Wang, Z.W.; Shen, Q. HMGB1 enhances the proinflammatory activity of lipopolysaccharide by promoting the phosphorylation of MAPK p38 through receptor for advanced glycation end products. J. Immunol. 2009, 183, 6244-6250. [CrossRef]

65. Kuzmich, N.N.; Sivak, K.V.; Chubarev, V.N.; Porozov, Y.B.; Savateeva-Lyubimova, T.N.; Peri, F. TLR4 Signaling Pathway Modulators as Potential Therapeutics in Inflammation and Sepsis. Vaccines 2017, 5, 34. [CrossRef]

66. Lau, C.; Gunnarsen, K.S.; Hoydahl, L.S.; Andersen, J.T.; Berntzen, G.; Pharo, A.; Lindstad, J.K.; Ludviksen, J.K.; Brekke, O.L.; Barratt-Due, A.; et al. Chimeric anti-CD14 IGG2/4 Hybrid antibodies for therapeutic intervention in pig and human models of inflammation. J. Immunol. 2013, 191, 4769-4777. [CrossRef]

67. Skjeflo, E.W.; Sagatun, C.; Dybwik, K.; Aam, S.; Urving, S.H.; Nunn, M.A.; Fure, H.; Lau, C.; Brekke, O.L.; Huber-Lang, M.; et al. Combined inhibition of complement and CD14 improved outcome in porcine polymicrobial sepsis. Crit. Care 2015, 19, 415. [CrossRef]

68. Thorgersen, E.B.; Pischke, S.E.; Barratt-Due, A.; Fure, H.; Lindstad, J.K.; Pharo, A.; Hellerud, B.C.; Mollnes, T.E. Systemic CD14 inhibition attenuates organ inflammation in porcine Escherichia coli sepsis. Infect. Immun. 2013, 81, 3173-3181. [CrossRef]

69. Mussap, M.; Puxeddu, E.; Puddu, M.; Ottonello, G.; Coghe, F.; Comite, P.; Cibecchini, F.; Fanos, V. Soluble CD14 subtype (sCD14-ST) presepsin in premature and full term critically ill newborns with sepsis and SIRS. Clin. Chim. Acta 2015, 451, 65-70. [CrossRef]

70. Chen, L.; Yu, J. Modulation of Toll-like receptor signaling in innate immunity by natural products. Int. Immunopharmacol. 2016, 37, 65-70. [CrossRef]

71. Kanmani, P.; Ansari, A.; Villena, J.; Kim, H. Immunobiotics beneficially modulate TLR4 signaling triggered by lipopolysaccharide and reduce hepatic steatosis in vitro. J. Immunol. Res. 2019, 2019, 3876896. [CrossRef] [PubMed]

72. Finamore, A.; Roselli, M.; Imbinto, A.; Seeboth, J.; Oswald, I.P.; Mengheri, E. Lactobacillus amylovorus inhibits the TLR4 inflammatory signaling triggered by enterotoxigenic Escherichia coli via modulation of the negative regulators and involvement of TLR2 in intestinal Caco-2 cells and pig explants. PLoS ONE 2014, 9, e94891. [CrossRef] [PubMed]

73. Akira, S.; Uematsu, S.; Takeuchi, O. Pathogen recognition and innate immunity. Cell 2006, 124, $783-801$. [CrossRef] [PubMed]

74. Beveridge, T.J. Structures of gram-negative cell walls and their derived membrane vesicles. J. Bacteriol. 1999, 181, 4725-4733. [PubMed]

75. Kaparakis-Liaskos, M.; Ferrero, R.L. Immune modulation by bacterial outer membrane vesicles. Nat. Rev. Immunol. 2015, 15, 375-387. [CrossRef] [PubMed]

76. Li, N.; Huang, S.; Jiang, L.; Dai, Z.; Li, T.; Han, D.; Wang, J. Characterization of the early life microbiota development and predominant Lactobacillus species at distinct gut segments of low- and normal-birth-weight piglets. Front. Microbiol. 2019, 10, 797. [CrossRef] [PubMed]

77. Kanmani, P.; Kim, H. Functional capabilities of probiotic strains on attenuation of intestinal epithelial cell inflammatory response induced by TLR4 stimuli. Biofactors 2019, 45, 223-235. [CrossRef]

78. Yi, H.; Wang, L.; Xiong, Y.; Wen, X.; Wang, Z.; Yang, X.; Gao, K.; Jiang, Z. Effects of Lactobacillus reuteri LR1 on the growth performance, intestinal morphology, and intestinal barrier function in weaned pigs. J. Anim. Sci. 2018, 96, 2342-2351. [CrossRef]

79. Roselli, M.; Finamore, A.; Britti, M.S.; Konstantinov, S.R.; Smidt, H.; de Vos, W.M.; Mengheri, E. The novel porcine Lactobacillus sobrius strain protects intestinal cells from enterotoxigenic Escherichia coli K88 infection and prevents membrane barrier damage. J. Nutr. 2007, 137, 2709-2716. [CrossRef]

80. Roos, S.; Karner, F.; Axelsson, L.; Jonsson, H. Lactobacillus mucosae sp. nov., a new species with in vitro mucus-binding activity isolated from pig intestine. Int. J. Syst. Evol. Microbiol. 2000, 50, 251-258. [CrossRef] 
81. Grozdanov, L.; Zahringer, U.; Blum-Oehler, G.; Brade, L.; Henne, A.; Knirel, Y.A.; Schombel, U.; Schulze, J.; Sonnenborn, U.; Gottschalk, G.; et al. A single nucleotide exchange in the wzy gene is responsible for the semirough O6 lipopolysaccharide phenotype and serum sensitivity of Escherichia coli strain Nissle 1917. J. Bacteriol. 2002, 184, 5912-5925. [CrossRef]

82. Secher, T.; Brehin, C.; Oswald, E. Early settlers: Which E. coli strains do you not want at birth? Am J Physiol Gastrointest. Liver Physiol. 2016, 311, G123-G129. [CrossRef]

83. Foster, N.; Lovell, M.A.; Marston, K.L.; Hulme, S.D.; Frost, A.J.; Bland, P.; Barrow, P.A. Rapid protection of gnotobiotic pigs against experimental salmonellosis following induction of polymorphonuclear leukocytes by avirulent Salmonella enterica. Infect. Immun. 2003, 71, 2182-2191. [CrossRef]

84. Splichal, I.; Trebichavsky, I.; Splichalova, A.; Barrow, P.A. Protection of gnotobiotic pigs against Salmonella enterica serotype Typhimurium by rough mutant of the same serotype is accompanied by the change of local and systemic cytokine response. Vet. Immunol. Immunopathol. 2005, 103, 155-161. [CrossRef]

85. Zughaier, S.M.; Zimmer, S.M.; Datta, A.; Carlson, R.W.; Stephens, D.S. Differential induction of the toll-like receptor 4-MyD88-dependent and -independent signaling pathways by endotoxins. Infect. Immun. 2005, 73, 2940-2950. [CrossRef]

86. Raby, A.C.; Holst, B.; Le, B.E.; Diaz, C.; Ferran, E.; Conraux, L.; Guillemot, J.C.; Coles, B.; Kift-Morgan, A.; Colmont, C.S.; et al. Targeting the TLR co-receptor CD14 with TLR2-derived peptides modulates immune responses to pathogens. Sci. Transl. Med. 2013, 5, 185ra64. [CrossRef]

87. Baumann, C.L.; Aspalter, I.M.; Sharif, O.; Pichlmair, A.; Bluml, S.; Grebien, F.; Bruckner, M.; Pasierbek, P.; Aumayr, K.; Planyavsky, M.; et al. CD14 is a coreceptor of Toll-like receptors 7 and 9. J. Exp. Med. 2010, 207, 2689-2701. [CrossRef]

88. Thorgersen, E.B.; Hellerud, B.C.; Nielsen, E.W.; Barratt-Due, A.; Fure, H.; Lindstad, J.K.; Pharo, A.; Fosse, E.; Tonnessen, T.I.; Johansen, H.T.; et al. CD14 inhibition efficiently attenuates early inflammatory and hemostatic responses in Escherichia coli sepsis in pigs. FASEB J. 2010, 24, 712-722. [CrossRef]

89. Zhan, R.; Han, Q.; Zhang, C.; Tian, Z.; Zhang, J. Toll-Like receptor 2 (TLR2) and TLR9 play opposing roles in host innate immunity against Salmonella enterica serovar Typhimurium infection. Infect. Immun. 2015, 83, 1641-1649. [CrossRef]

90. Grabig, A.; Paclik, D.; Guzy, C.; Dankof, A.; Baumgart, D.C.; Erckenbrecht, J.; Raupach, B.; Sonnenborn, U.; Eckert, J.; Schumann, R.R.; et al. Escherichia coli strain Nissle 1917 ameliorates experimental colitis via toll-like receptor 2- and toll-like receptor 4-dependent pathways. Infect. Immun. 2006, 74, 4075-4082. [CrossRef]

91. Uribe, J.H.; Collado-Romero, M.; Zaldivar-Lopez, S.; Arce, C.; Bautista, R.; Carvajal, A.; Cirera, S.; Claros, M.G.; Garrido, J.J. Transcriptional analysis of porcine intestinal mucosa infected with Salmonella Typhimurium revealed a massive inflammatory response and disruption of bile acid absorption in ileum. Vet. Res. 2016, 47, 11. [CrossRef]

92. Sheikh, I.A.; Ammoury, R.; Ghishan, F.K. Chapter 68-Pathophysiology of Diarrhea and Its Clinical Implications. In Physiology of the Gastrointestinal Tract, 6th ed.; Said, H.M., Ed.; Academic Press-Elsevier Inc.: Amsterdam, The Netherlands, 2018; pp. 1669-1687.

93. Pieper, R.; Janczyk, P.; Zeyner, A.; Smidt, H.; Guiard, V.; Souffrant, W.B. Ecophysiology of the developing total bacterial and lactobacillus communities in the terminal small intestine of weaning piglets. Microb. Ecol. 2008, 56, 474-483. [CrossRef]

94. Collado-Romero, M.; Arce, C.; Ramirez-Boo, M.; Carvajal, A.; Garrido, J.J. Quantitative analysis of the immune response upon Salmonella typhimurium infection along the porcine intestinal gut. Vet. Res. 2010, 41, 23. [CrossRef]

95. Bravo-Blas, A.; Utriainen, L.; Clay, S.L.; Kastele, V.; Cerovic, V.; Cunningham, A.F.; Henderson, I.R.; Wall, D.M.; Milling, S.W.F. Salmonella enterica serovar Typhimurium travels to mesenteric lymph nodes both with host cells and autonomously. J. Immunol. 2019, 202, 260-267. [CrossRef]

96. Neutra, M.R.; Mantis, N.J.; Kraehenbuhl, J.P. Collaboration of epithelial cells with organized mucosal lymphoid tissues. Nat. Immunol. 2001, 2, 1004-1009. [CrossRef]

97. Voedisch, S.; Koenecke, C.; David, S.; Herbrand, H.; Forster, R.; Rhen, M.; Pabst, O. Mesenteric lymph nodes confine dendritic cell-mediated dissemination of Salmonella enterica serovar Typhimurium and limit systemic disease in mice. Infect. Immun. 2009, 77, 3170-3180. [CrossRef]

98. Delves, P.J.; Roitt, I.M. The immune system. First of two parts. N. Engl. J. Med. 2000, 343, 37-49. [CrossRef] 
99. Tohno, M.; Shimosato, T.; Moue, M.; Aso, H.; Watanabe, K.; Kawai, Y.; Yamaguchi, T.; Saito, T.; Kitazawa, H. Toll-like receptor 2 and 9 are expressed and functional in gut-associated lymphoid tissues of presuckling newborn swine. Vet. Res. 2006, 37, 791-812. [CrossRef]

100. Dziarski, R.; Wang, Q.; Miyake, K.; Kirschning, C.J.; Gupta, D. MD-2 enables Toll-like receptor 2 (TLR2)-mediated responses to lipopolysaccharide and enhances TLR2-mediated responses to Gram-positive and Gram-negative bacteria and their cell wall components. J. Immunol. 2001, 166, 1938-1944. [CrossRef]

101. Martins, R.P.; Collado-Romero, M.; Arce, C.; Lucena, C.; Carvajal, A.; Garrido, J.J. Exploring the immune response of porcine mesenteric lymph nodes to Salmonella enterica serovar Typhimurium: An analysis of transcriptional changes, morphological alterations and pathogen burden. Comp. Immunol. Microbiol. Infect. Dis. 2013, 36, 149-160. [CrossRef]

102. Bucciarelli, L.G.; Wendt, T.; Rong, L.; Lalla, E.; Hofmann, M.A.; Goova, M.T.; Taguchi, A.; Yan, S.F.; Yan, S.D.; Stern, D.M.; et al. RAGE is a multiligand receptor of the immunoglobulin superfamily: Implications for homeostasis and chronic disease. Cell Mol. Life Sci. 2002, 59, 1117-1128. [CrossRef]

103. Splichalova, A.; Splichal, I.; Chmelarova, P.; Trebichavsky, I. Alarmin HMGB1 is released in the small intestine of gnotobiotic piglets infected with enteric pathogens and its level in plasma reflects severity of sepsis. J. Clin. Immunol. 2011, 31, 488-497. [CrossRef]

104. Vitali, R.; Stronati, L.; Negroni, A.; Di Nardo, G.; Pierdomenico, M.; Del Giudice, E.; Rossi, P.; Cucchiara, S. Fecal HMGB1 is a novel marker of intestinal mucosal inflammation in pediatric inflammatory bowel disease. Am. J. Gastroenterol. 2011, 106, 2029-2040. [CrossRef]

105. Mihi, B.; Good, M. Impact of Toll-Like Receptor 4 Signaling in Necrotizing Enterocolitis: The State of the Science. Clin. Perinatol. 2019, 46, 145-157. [CrossRef]

106. Hong, C.R.; Han, S.M.; Jaksic, T. Surgical considerations for neonates with necrotizing enterocolitis. Semin. Fetal Neonatal. Med. 2018, 23, 420-425. [CrossRef]

107. Zhang, S.; Kingsley, R.A.; Santos, R.L.; Andrews-Polymenis, H.; Raffatellu, M.; Figueiredo, J.; Nunes, J.; Tsolis, R.M.; Adams, L.G.; Baumler, A.J. Molecular pathogenesis of Salmonella enterica serotype Typhimurium-induced diarrhea. Infect. Immun. 2003, 71, 1-12. [CrossRef]

108. Yu, R.; Jiang, S.; Tao, Y.; Li, P.; Yin, J.; Zhou, Q. Inhibition of HMGB1 improves necrotizing enterocolitis by inhibiting NLRP3 via TLR4 and NF-kappaB signaling pathways. J. Cell Physiol. 2019, 234, 13431-13438. [CrossRef]

109. Splichalova, A.; Splichal, I. Local and systemic occurrences of HMGB1 in gnotobiotic piglets infected with E. coli $\mathrm{O} 55$ are related to bacterial translocation and inflammatory cytokines. Cytokine 2012, 60, 597-600. [CrossRef]

110. Shi, H.; Huang, X.; Yan, Z.; Yang, Q.; Wang, P.; Li, S.; Sun, W.; Gun, S. Effect of Clostridium perfringens type C on TLR4/MyD88/NF-kappaB signaling pathway in piglet small intestines. Microb. Pathog. 2019, 135, 103567. [CrossRef]

111. Gardella, S.; Andrei, C.; Ferrera, D.; Lotti, L.V.; Torrisi, M.R.; Bianchi, M.E.; Rubartelli, A. The nuclear protein HMGB1 is secreted by monocytes via a non-classical, vesicle-mediated secretory pathway. EMBO Rep. 2002, 3, 995-1001. [CrossRef]

112. Youn, J.H.; Oh, Y.J.; Kim, E.S.; Choi, J.E.; Shin, J.S. High mobility group box 1 protein binding to lipopolysaccharide facilitates transfer of lipopolysaccharide to CD14 and enhances lipopolysaccharide-mediated TNF-alpha production in human monocytes. J. Immunol. 2008, 180, 5067-5074. [CrossRef]

113. Schmittgen, T.D.; Livak, K.J. Analyzing real-time PCR data by the comparative C(T) method. Nat. Protoc. 2008, 3, 1101-1108. [CrossRef]

114. Schneider, C.A.; Rasband, W.S.; Eliceiri, K.W. NIH Image to ImageJ: 25 years of image analysis. Nat. Methods 2012, 9, 671-675. [CrossRef]

(C) 2019 by the authors. Licensee MDPI, Basel, Switzerland. This article is an open access article distributed under the terms and conditions of the Creative Commons Attribution (CC BY) license (http://creativecommons.org/licenses/by/4.0/). 